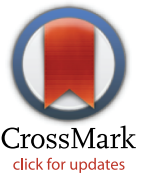

click for updates
RESEARCH ARTICLE

\section{Low $\mathrm{CO}_{2}$ Sensitivity of Microzooplankton Communities in the Gullmar Fjord, Skagerrak: Evidence from a Long-Term Mesocosm Study}

\author{
Henriette G. Horn ${ }^{1}$ *, Nils Sander ${ }^{1}$, Annegret Stuhr ${ }^{2}$, María Algueró-Muñiz ${ }^{1}$, Lennart \\ T. Bach ${ }^{2}$, Martin G. J. Löder ${ }^{3}$, Maarten Boersma ${ }^{1,4}$, Ulf Riebesell ${ }^{2}$, Nicole Aberle ${ }^{1 \text { मа }}$
}

1 Alfred-Wegener-Institut Helmholtz-Zentrum für Polar- und Meeresforschung, Biologische Anstalt Helgoland, Helgoland, Germany, 2 GEOMAR Helmholtz Centre for Ocean Research Kiel, Kiel, Germany, 3 Animal Ecology I, University of Bayreuth, Bayreuth, Germany, 4 University of Bremen, Bremen, Germany

a Current address: Department of Biology, NTNU Norwegian University of Science and Technology, Trondheim, Norway

* henriette.horn@awi.de

\section{Abstract}

Ocean acidification is considered as a crucial stressor for marine communities. In this study, we tested the effects of the IPCC RPC6.0 end-of-century acidification scenario on a natural plankton community in the Gullmar Fjord, Sweden, during a long-term mesocosm experiment from a spring bloom to a mid-summer situation. The focus of this study was on microzooplankton and its interactions with phytoplankton and mesozooplankton. The microzooplankton community was dominated by ciliates, especially small Strombidium sp., with the exception of the last days when heterotrophic dinoflagellates increased in abundance. We did not observe any effects of high $\mathrm{CO}_{2}$ on the community composition and diversity of microzooplankton. While ciliate abundance, biomass and growth rate were not affected by elevated $\mathrm{CO}_{2}$, we observed a positive effect of elevated $\mathrm{CO}_{2}$ on dinoflagellate abundances. Additionally, growth rates of dinoflagellates were significantly higher in the high $\mathrm{CO}_{2}$ treatments. Given the higher Chlorophyll a content measured under high $\mathrm{CO}_{2}$, our results point at mainly indirect effects of $\mathrm{CO}_{2}$ on microzooplankton caused by changes in phytoplankton standing stocks, in this case most likely an increase in small-sized phytoplankton of $<8 \mu \mathrm{m}$. Overall, the results from the present study covering the most important part of the growing season indicate that coastal microzooplankton communities are rather robust towards realistic acidification scenarios.

\section{Introduction}

Atmospheric $\mathrm{CO}_{2}$ concentrations have increased considerably from $280 \mu$ atm at pre-industrial times to currently about $400 \mu \mathrm{atm}$ [1] and are predicted to reach up to $1000 \mu \mathrm{atm}$ by the end of this century (IPCC scenario RPC6.0) [2]. The oceans act as a major $\mathrm{CO}_{2}$ sink and have absorbed about $30 \%$ of the anthropogenic $\mathrm{CO}_{2}$ since the beginning of the industrial revolution [3]. This obviously has affected the ocean's carbonate system, leading to increased $\mathrm{CO}_{2}$ and 
role in study design, data collection and analysis, decision to publish, or preparation of the manuscript.

Competing Interests: The authors have declared that no competing interests exist. bicarbonate $\left(\mathrm{HCO}_{3}{ }^{-}\right)$concentrations as well as a decrease in carbonate ion concentrations $\left(\mathrm{CO}_{3}{ }^{2-}\right)$ and $\mathrm{pH}$. This drop in $\mathrm{pH}$ is referred to as ocean acidification (OA). While there are differences in $\mathrm{CO}_{2}$ uptake depending on the region [3], an overall $\mathrm{pH}$ decrease of about 0.3 units is expected until the end of the $21^{\text {st }}$ century [4].

Microzooplankton (MZP), plankton within the size class from 20 to $200 \mu \mathrm{m}$, is a heterogeneous group consisting of heterotrophic and mixotrophic protists as well as micrometazoa. Often grazing on an average $60-75 \%$ of the daily primary production, it is a dietary competitor for larger mesozooplankton [5,6]. Accordingly, MZP can have a strong impact on biomass and species composition of the phytoplankton community and even play an important role in suppressing phytoplankton blooms, especially at times when mesozooplankton grazing is low [7]. Moreover, MZP can also be strongly top-down controlled itself, as it is a preferred food source for mesozooplankton such as copepods $[5,8]$.

$\mathrm{OA}$ is predicted to affect different marine biological and biogeochemical processes, potentially resulting in adverse effects not only on the species level but also on the community and ecosystem level [9]. Potential direct effects of OA on MZP have been identified as e.g. changes in intracellular $\mathrm{pH}$ or enzyme activities [10], and indeed negative effects such as a decrease in biomass or the inhibition of growth have been reported for some species of MZP [11, 12]. Others, however, were not directly affected by a change in $\mathrm{pH}[13]$. Nonetheless, $\mathrm{CO}_{2}$ effects can also be transmitted indirectly, via changes in phytoplankton availability, community composition, or food quality $[14,15]$. Based on the enhanced growth of especially small-sized phytoplankton species which benefit from the higher carbon availability under OA [16-19], OA has the potential to lead to an increase in MZP productivity as well.

Despite of the pivotal role of MZP, small-scale laboratory experiments providing information about the impacts of $\mathrm{OA}$ on single species or simplified food webs are comparatively rare in contrast to the number of studies available for phytoplankton or mesozooplankton (e.g. [20, 21]). Additionally, there is a lack of information about OA impacts on community level. Mesocosm studies are useful to fill this gap as they allow us to gain insight into the effects of OA on the plankton community and whether biotic interactions could dampen or amplify known responses in MZP $[15,22]$. The studies available so far indicate that MZP communities, especially in coastal areas, are rather tolerant to OA at incubation times up to weeks [22-25]. Yet, to study evolutionary adaptations to OA which are likely to occur due to the short generation times of planktonic organisms, long-term experiments would be required [26]. Experiments with longer durations are also necessary to allow observing possible numerical responses of mesozooplankton as it reacts time-delayed to $\mathrm{CO}_{2}$-induced changes on phytoplankton or MZP level. Consequently, an in-situ mesocosm approach using a natural plankton assemblage and a sufficiently large incubation volume to allow for a long self-sustained runtime is a step towards the understanding of effects on ecosystem level [27].

We investigated the impacts of high $\mathrm{CO}_{2}$ levels on natural plankton communities during a long-term mesocosm study in the Gullmar Fjord, Skagerrak. Starting before the onset of the spring bloom in March, the long runtime until end of June made it possible to follow the natural succession of a plankton community during the transition from spring to summer. In the following, we will present the analysis of MZP succession patterns focusing on ciliates and heterotrophic dinoflagellates and their interactions with phytoplankton.

Moreover, grazing experiments should provide additional information both regarding the grazing impact of MZP and indirect effects of a high $\mathrm{CO}_{2}$ level which are more likely to be detected when MZP is released from grazing pressure. Our hypotheses considering the effects of high $\mathrm{CO}_{2}$ on MZP were as follows:

1. Elevated $\mathrm{CO}_{2}$ will not directly affect MZP communities due to their high $\mathrm{CO}_{2}$ tolerance. 
2. An increase in phytoplankton biomass at high $\mathrm{CO}_{2}$ conditions (due to positive effects on photosynthesis) will lead to enhanced MZP biomass and grazing rates.

3. Small sized phytoplankton will profit from high $\mathrm{CO}_{2}$ levels which is in favor of MZP grazers but not mesozooplankton thus in turn, grazing pressure on MZP will increase.

\section{Material and methods}

\subsection{Experimental design}

The setup is described in detail by Bach et al. [28], including mesocosm design, $\mathrm{CO}_{2}$ addition, and maintenance work during the experiment, to which we refer the reader for further information. In short, ten"Kiel offshore mesocosms for future ocean simulations" (KOSMOS) [27] with a volume of $55 \mathrm{~m}^{3}$ each were moored in the Gullmar Fjord on the Swedish west coast at $58^{\circ} 15^{\prime} 9 \mathrm{~N}, 11^{\circ} 28^{\prime} 7 \mathrm{E}$ in January 2013 . Each mesocosm made of polyurethane foil had a diameter of $2 \mathrm{~m}$ and was $19 \mathrm{~m}$ long, with a conical sediment trap at the lower end. The upper part of the mesocosms was $\sim 2 \mathrm{~m}$ above the sea surface, open to allow gas exchange with the surrounding and protected against birds with a transparent roof mounted on the floatation frame. The experiment ran from 7 March till 26 June 2013. Upon closing of the mesocosms, a net with 1 $\mathrm{mm}$ mesh size was passed through the enclosed pre-bloom seawater to remove large organisms. Five mesocosms served as control with ambient $\mathrm{CO}_{2}$ levels while $\mathrm{CO}_{2}$-enriched seawater was added to the other five.

The chosen $\mathrm{CO}_{2}$ level of $760 \mu$ atm corresponds to the conditions expected for the end of the $21^{\text {st }}$ century according to IPCC scenario RPC6.0 [2]. In order to compensate for outgassing, $\mathrm{CO}_{2}$-enriched water was added to the high $\mathrm{CO}_{2}$ treatments at five time points (days 17, 46, 48, 68 and 88). Herring larvae (Clupea harengus) and sea urchin larvae (Strongylocentrotus droebrachiensis) were added to the mesocosms on day 48 and day 56 of the experiment, respectively. Regular sampling every $2^{\text {nd }}$ day included CTD casts, water column sampling, and sediment sampling. Plankton net hauls were performed every eight days. For the water samples, two $10 \mathrm{~L}$ carboys per mesocosm were filled using an integrating water sampler (IWS III, Hydro-Bios) over a depth of 0-17 m. Plankton samples were taken from the carboys as soon as they were back on shore.

\subsection{Sampling and identification of MZP}

MZP samples were taken once per week. $250 \mathrm{~mL}$ of mesocosm water was transferred into brown glass bottles and fixed with acidic Lugol's solution ( $1 \%$ final concentration). MZP was counted and identified with an inverted microscope (Zeiss Axiovert 135) using the Utermöhl method [29]. Depending on the plankton abundance, 50 or $100 \mathrm{~mL}$ of each sample were transferred into a sedimentation chamber. After $24 \mathrm{~h}$ of sedimentation, the whole surface of the chamber was counted at 200 -fold magnification to reduce the counting bias against rare species and to assure comparability of the counts both at high and low abundances.

MZP was identified to the lowest possible taxonomic level (species or genus level) according to Carey [30], Montagnes et al. [31], and Kraberg et al. [32] and otherwise grouped into size classes. Most dinoflagellates are capable of heterotrophic feeding modes and can be considered as mixotrophic MZP. Only few taxa such as Ceratium sp. were considered as predominantly autotrophic and thus included in the phytoplankton. Based on the digitally measured dimensions of 20 random cells per species or size class distinguished (AxioVision 4.9 and AxioCam, Carl Zeiss Microscopy $\mathrm{GmbH}$ ), biovolumes of MZP were calculated using geometric proxies by Hillebrand et al. [33]. MZP carbon biomass was estimated from the biovolumes using the 
conversion factors provided by Putt and Stoecker [34] and Menden-Deuer and Lessard [35] for ciliates and dinoflagellates, respectively.

\subsection{Sampling and identification of phytoplankton}

Samples of small-sized phytoplankton $(<8 \mu \mathrm{m})$ were measured every $2^{\text {nd }}$ day with an Accuri C6 flow cytometer (BD Biosciences) within three hours after mesocosm sampling was completed. Another $250 \mathrm{~mL}$ of mesocosm water was fixed with acidic Lugol's iodine (1\% final concentration). Large phytoplankton cells $(>8 \mu \mathrm{m})$ were counted on ten sampling days around the start of the experiment, the phytoplankton bloom peaks and the end. Counts were done on $50 \mathrm{~mL}$ concentrated sample water with an inverted microscope (Zeiss Axiovert 100) after Utermöhl [29]. The cells were counted either on half or total area of the chamber at 100-fold magnification or on 2 to 4 stripes at 200 or 400 -fold magnification. Plankton were identified following Tomas et al. [36], Hoppenrath et al. [37], and Kraberg et al. [32].

\subsection{Data analysis}

Diversity $\left(H^{\prime}, \log _{\mathrm{e}}\right)$ was calculated after Shannon and Weaver [38] on a sample day basis. The bloom timing $\left(\mathrm{D}_{\max }\right)$ was defined as the experimental day when phytoplankton abundance or MZP biomass reached its peak in each mesocosm (max.). Net growth rates $\mu$ were calculated using an exponential growth model [39]:

$$
\mu=\frac{1}{t} \ln \frac{P_{24}}{P_{0}}
$$

where $P_{0}$ and $P_{24}$ are the plankton concentrations on the first day of finding and on $\mathrm{D}_{\max }$ and $t$ is the time in between these days.

$\mathrm{D}_{\max }$, maximum and net growth rate data were first tested for normality and homogeneity using a Shapiro-Wilk test and Levene's Test for Homogeneity of Variance and log transformed if necessary. For analysing the effects of $p \mathrm{CO}_{2}$ on these variables, ANOVAs were performed. Tukey's HSD was used as post-hoc test. To test for significant effects of $p \mathrm{CO}_{2}$ on MZP and phytoplankton biomass, abundance and species diversity over time, a Generalized Additive Mixed Model (GAMM) was applied. "Mesocosm" was added as random effect to test if there was an effect of the position of the mesocosms on the parameters. Biomass, abundance and diversity data were log transformed if it improved the outcome of the GAMM as indicated by the $\mathrm{R}^{2}$ value. $\mathrm{R}$ Studio was used for all analyses with the additional packages $m g c v$, vegan and car (Version 0.95.265, RStudio, Inc.).

\subsection{Dilution experiment}

Setup. In order to further investigate the impact of microzooplankton grazing on phytoplankton, a dilution experiment after Landry and Hassett [39] was conducted. The experiment took place on day 34 during the $1^{\text {st }}$ phytoplankton bloom peak to ensure high phytoplankton densities in the samples. By releasing the MZP from copepod grazing pressure, indirect effects of $\mathrm{CO}_{2}$ on MZP based on changes in phytoplankton abundance or composition are more likely to become visible. Additionally, this grazing setup allows the determination of the natural taxon-specific phytoplankton growth rates despite of a separation of phytoplankton and micrograzers not being possible due to their similar size.

$15 \mathrm{~L}$ mesocosm water was sampled with an integrating water sampler from 6 out of 10 mesocosms selected for the experiment. To exclude mesozooplankton, the mesocosm water was pre-screened with a $200 \mu \mathrm{m}$ mesh. For setting up the dilutions, filtered mesocosm water was obtained by using $0.45 / 0.2 \mu \mathrm{m}$ sterile inline membrane filters (Sartobran $\AA$ P 300, 
Sartorius AG). Three dilutions of 10, 25 and $50 \%$ as well as a setup with $100 \%$ undiluted mesocosm water were prepared in carboys. To prevent a bias due to nutrient limitation, sterile filtered nutrient solutions ( $\mathrm{F} / 2$ medium after [40], reduced by half) were added to the carboys; vitamin solution, trace metal solution, $\mathrm{NaNO}_{3}, \mathrm{Na}_{2} \mathrm{HPO}_{4}\left(1 \mathrm{~mL} \mathrm{~L}^{-1}\right)$ and $\mathrm{Na}_{2} \mathrm{SiF}_{6}\left(2 \mathrm{~mL} \mathrm{~L}^{-1}\right)$.

In triplicates, the dilutions were gently transferred into $0.5 \mathrm{~L}$ polycarbonate incubation bottles to avoid damaging the plankton. Three additional incubation bottles of $100 \%$ undiluted water were set up per mesocosm with the addition of five adult copepods (Pseudocalanus acuspes) collected from the regular mesozooplankton net tow the day before to analyze mesozooplankton grazing. Animals were picked under a stereomicroscope and were kept in $1 \mathrm{~L}$ bottles filled with filtered sea water in the climate room overnight prior to addition to the incubation bottles. Another three incubation bottles per mesocosm were set up without the addition of nutrients to serve as control. Initial samples for MZP and phytoplankton starting densities were obtained from the carboys, transferred into brown glass bottles, and fixed with acid Lugol's solution. Incubation bottles were placed on a plankton wheel turning at low speed $(\sim 1.1 \mathrm{rpm})$ at ambient temperature $\left(5^{\circ} \mathrm{C}\right.$ during this experiment $)$ and light conditions in a climate controlled room. After $24 \mathrm{~h}$, samples were taken from every incubation bottle.

MZP was analyzed as described in the previous section. For phytoplankton counts, in principle the same method was used as previously described but with a sample volume between 10 and $50 \mathrm{~mL}$ depending on the phytoplankton abundance. At least 400 cells per abundant taxon were counted in tracks of the sedimentation slide using a Zeiss Axiovert 135 inverted microscope. Phytoplankton was identified after Tomas et al. [36] and Kraberg et al. [32] and otherwise assigned to a size class. For the estimation of phytoplankton biovolume 20 pictures per species or size class distinguished were taken (AxioVision 4.9 and AxioCam, Carl Zeiss Microscopy GmbH) and digitally measured with ImageJ (Version 1.49). Phytoplankton biovolumes were calculated from the measurements according to Hillebrand et al. [33] and converted to carbon biomass [34, 35].

From the values obtained from the initial 100\% sample, starting values for the diluted samples were calculated according to their dilution factor. Phytoplankton net growth per day $\mu$ was calculated using an exponential growth model as described in Eq (1). The actual phytoplankton growth rate $k$ and phytoplankton grazing mortality $m$ were obtained from a linear regression of the dilution factor $\alpha$ against the phytoplankton growth $\mu_{\alpha}$ where $k$ is the intercept with the $y$-axis and $m$ is the slope of the regression $[39,41]$ :

$$
\mu_{\alpha}=k+m \alpha
$$

The MZP grazing rate $g$ is the negative phytoplankton mortality. All negative grazing rates were set to zero. To calculate the instantaneous (natural) phytoplankton growth rate $\mu_{0}$, grazing mortality $m$ was added to the net growth rate $\mu$ obtained from the controls grown without the addition of nutrients. All data were first tested for normality and homogeneity with a ShapiroWilk test and a Levene's Test for Homogeneity of Variance. Effects of $\mathrm{CO}_{2}$ and copepod addition on phytoplankton growth rate $k$, phytoplankton grazing mortality $m$ and instantaneous phytoplankton growth rate $\mu_{0}$ were tested using ANOVAs. Tukey's HSD test was used as post hoc test.

\subsection{Community grazing experiment}

Setup. In addition to the dilution experiment, community grazing experiments were performed twice during the mesocosm study. While they do not allow for determination of natural phytoplankton growth rates, phytoplankton net growth rates $\mu$ including the MZP grazing impact can be obtained. Moreover, they allow the calculation of MZP growth rates. The time points chosen were day 37 and 53 , after the $1^{\text {st }}$ and the $2^{\text {nd }}$ phytoplankton bloom peaks. 
From each mesocosm, $5 \mathrm{~L}$ of seawater was sampled with an integrating water sampler. Two incubation bottles were set up per mesocosm, one containing unfiltered mesocosm water including mesozooplankton grazers (+G treatment) while the other was filled with prescreened water (100 $\mu \mathrm{m}$ mesh size) to exclude them (-G treatment). It has to be noted that use of integrated water samplers led to an underestimation of the mesozooplankton grazing impact as copepods were partly able to escape from the sampler. Control of the copepod abundances revealed an abundance reduction by half compared to the mesocosms. Nutrients were not added to the incubation bottles. $250 \mathrm{~mL}$ sample of unfiltered and of pre-screened mesocosm water was transferred to brown glass bottles and fixed with acid Lugol's solution at the beginning of each experiment. Samples from every incubation bottle were taken after $24 \mathrm{~h}$ of incubation at ambient conditions using a plankton wheel. MZP and phytoplankton were counted microscopically as described for the dilution experiment.

Phytoplankton and MZP growth rates were calculated with Eq (1) as previously described. Data were tested for normality and homogeneity and transformed $(\log x+1)$ if necessary prior to analyzing the effects of $\mathrm{CO}_{2}$ and grazer presence using a Two-Way ANOVA.

\section{Results}

The experiment ran from 7 March (day -2) until 26 June (day 111). MZP sampling took place from 10 March until 20 June. Within this time, temperature increased from $1.5^{\circ} \mathrm{C}( \pm 0.06)$ to $15.4^{\circ} \mathrm{C}( \pm 0)$ (Fig 1). Average $p \mathrm{CO}_{2}$ was $383 \mu$ atm $( \pm 100.46)$ in the low and $739 \mu$ atm $( \pm 167.11)$ in the high $\mathrm{CO}_{2}$ treatments. Despite of $\mathrm{CO}_{2}$ fluctuations in the mesocosms due to outgassing and subsequent addition of $\mathrm{CO}_{2}$-enriched water, the treatments did not overlap at any time point.

\subsection{Phytoplankton succession and community composition}

Starting conditions on 10 March 2013 were Chlorophyll $a$ (in the following: Chl $a$ ) concentrations of $0.363( \pm 0.014)$ and $0.357( \pm 0.013) \mu \mathrm{g} \mathrm{L}{ }^{-1}$ in the low and high $\mathrm{CO}_{2}$ mesocosms (Fig $2 \mathrm{~A})$. Based on the $\mathrm{Chl} a$ development, the experiment was divided in four phases: pre-bloom (until day 16), $1^{\text {st }}$ phytoplankton bloom (day 17-40), $2^{\text {nd }}$ phytoplankton bloom (day 41-79) and post-bloom phase (from day $80 \mathrm{on}$ ).

Total phytoplankton abundances at the beginning of the experiment (day -1) were at $1.89 \times 10^{7}\left( \pm 5.06 \times 10^{5}\right)$ and $2.06 \times 10^{7}\left( \pm 5.33 \times 10^{5}\right)$ cells $\mathrm{L}^{-1}$ in the low and high $\mathrm{CO}_{2}$ treatments (Fig $2 \mathrm{~B})$. During the $1^{\text {st }}$ phytoplankton bloom, the large phytoplankton size class $(>8 \mu \mathrm{m})$ reached up to $7.91 \times 10^{4}$ and $9.43 \times 10^{4}$ cells $\mathrm{L}^{-1}$ in the low and high $\mathrm{CO}_{2}$ treatments. Afterwards it decreased to $\sim 4.43 \times 10^{3}$ cells $\mathrm{L}^{-1}$ and did not form another bloom. In contrast, small-sized phytoplankton $(<8 \mu \mathrm{m})$ had abundances of up to $1.48 \times 10^{8}$ cells $\mathrm{L}^{-1}$ during the $1^{\text {st }}$ and $2^{\text {nd }}$ bloom phase under high $\mathrm{CO}_{2}$. In the low $\mathrm{CO}_{2}$ treatments, this size class reached lower abundances ( $\mathrm{p}$-value $=0.010$, Table 1 ) and peaked at $1.10 \times 10^{8}$ cells $\mathrm{L}^{-1}$ and $8.07 \times 10^{7}$ cells $\mathrm{L}^{-1}$ during the $1^{\text {st }}$ and $2^{\text {nd }}$ bloom phase, respectively. On day 105 at the end of the experiment, total phyto-

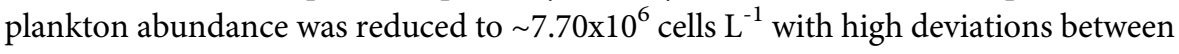
mesocosms.

In terms of abundance, pico- and nanophytoplankton of $<8 \mu \mathrm{m}$ contributed up to $99 \%$ of the total community. For the size class $<8 \mu \mathrm{m}$, abundance data from flow cytometry was used as it is more reliable than microscopy for small-sized taxa. Still, microscopic analysis of this size class revealed a dominance of the diatom Arcocellulus sp. as well as high abundances of the cryptophyte Hemiselmis sp.. Considering phytoplankton of $>8 \mu \mathrm{m}$ which was analyzed by microscopic counts, Teleaulax sp. and Thalassiosira sp. contributed the main part from the start of the experiment until the $1^{\text {st }}$ bloom (Fig 3 ). The large phytoplankton community 


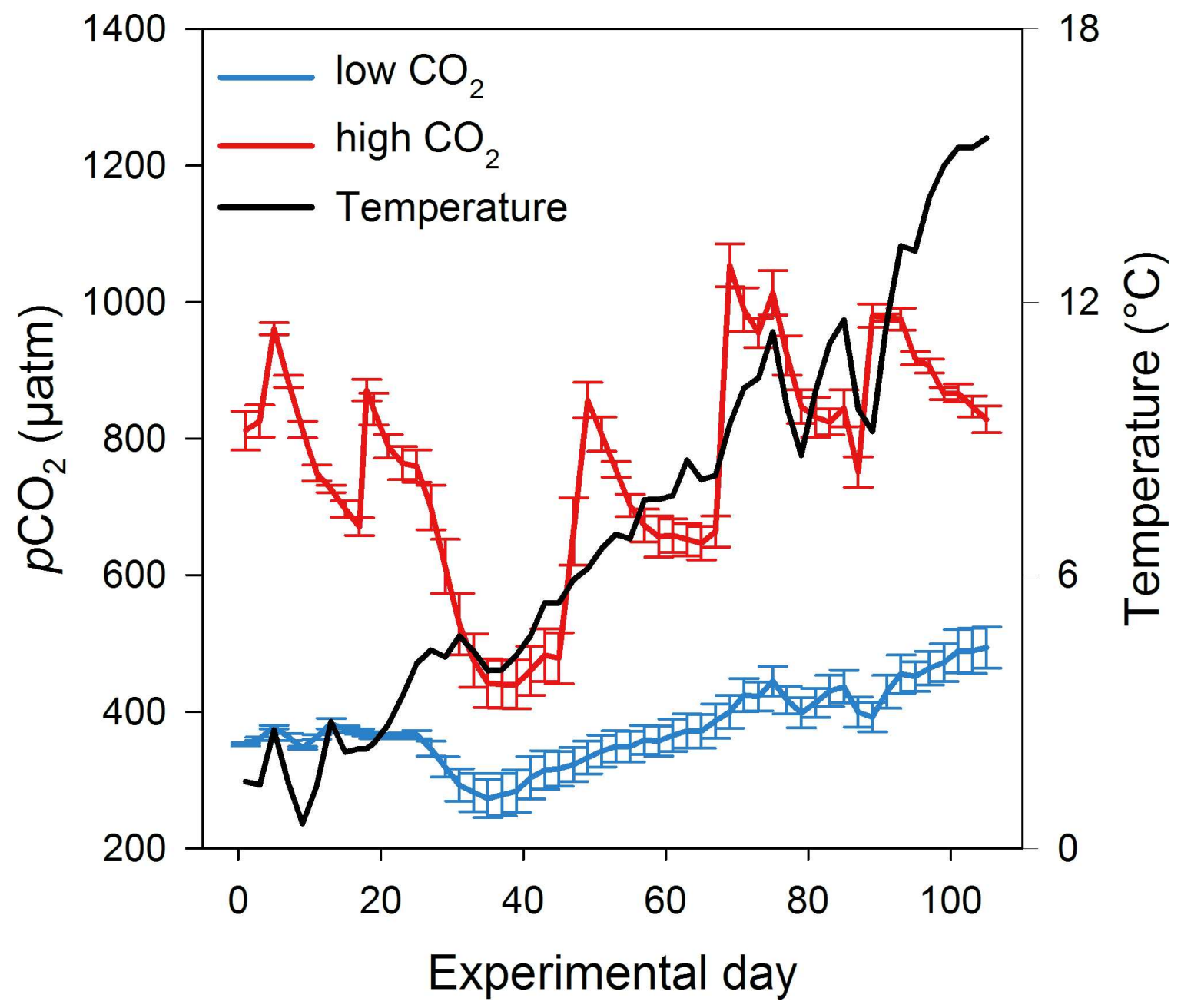

Fig 1. $\mathrm{CO}_{2}$ concentration and temperature development. Mean $\mathrm{CO}_{2}$ concentrations in the low (blue line) and high $\mathrm{CO}_{2}$ treatments (red line) are shown from day 1 to day 105 as well as mean temperature (black line). Error bars indicate the standard deviation.

doi:10.1371/journal.pone.0165800.g001

changed considerably after day 29 when both taxa disappeared and the remaining taxa reached very low abundances only, with the exception of Fragilaria sp.. Also Coscinodiscus sp. increased in numbers after day 29, especially in the low $\mathrm{CO}_{2}$ treatments. However, the increase of this large-sized diatom was mostly visible with regard to phytoplankton biomass. Nevertheless, while there was a positive $\mathrm{CO}_{2}$ effect on phytoplankton abundance for the size class $<8 \mu \mathrm{m}$ (Fig 2), abundance and species diversity for taxa $>8 \mu \mathrm{m}$ were not affected by the $\mathrm{CO}_{2}$ level in the data set we analyzed (Table 1). There was also no effect on phytoplankton abundance maximum or growth rates (Table 2).

\subsection{MZP succession}

Initial ciliate biomass was $4.23( \pm 0.82)$ for the low and $4.05( \pm 0.55) \mu \mathrm{g} \mathrm{C} \mathrm{L}{ }^{-1}$ for the high $\mathrm{CO}_{2}$ mesocosms (Fig 4A). Ciliate biomasses did not react to the $1^{\text {st }}$ bloom of the phytoplankton; only at the onset of the $2^{\text {nd }}$ bloom on day 40 we observed a first increase in biomass for both treatments. After a decline around day 73, ciliate biomass increased again until day 103, especially in the high $\mathrm{CO}_{2}$ treatments. The growth was most pronounced for the high $\mathrm{CO}_{2}$ 

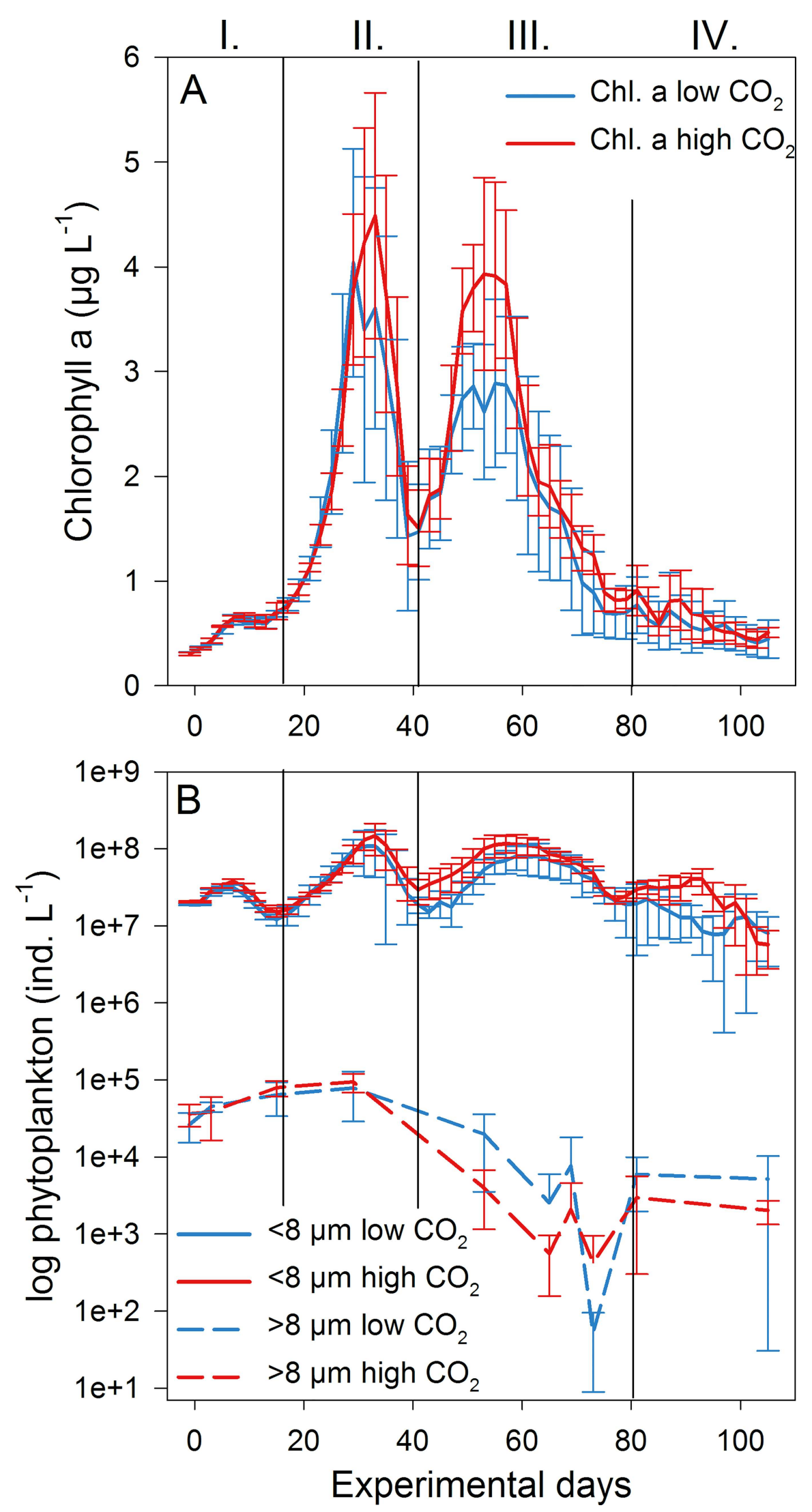
Fig 2. Phytoplankton succession. (A) Chlorophyll a concentrations from HPLC analysis in $\mu \mathrm{L} \mathrm{L}^{-1}$ at low (blue) and high $\mathrm{CO}_{2}$ (red). Error bars represent the standard deviation. Vertical black lines and Latin numbers indicate the experimental phases (I-IV). (B) Phytoplankton abundances in log ind. $\mathrm{L}^{-1}$ in the low and high $\mathrm{CO}_{2}$ treatments for pico- and nanophytoplankton $(<8 \mu \mathrm{m}$, solid lines) as well as large phytoplankton $(>8 \mu \mathrm{m}$, dashed lines).

doi:10.1371/journal.pone.0165800.g002

mesocosms MK7 and MK8, reaching 73.18 and $46.74 \mathrm{mg} \mathrm{C} \mathrm{L}^{-1}$. There was no $\mathrm{CO}_{2}$ effect on ciliate biomass, abundance or diversity throughout the experiment (Table 1).

Total dinoflagellate biomass stayed below $1.27( \pm 1.54)$ in the low and $1.56( \pm 2.05) \mu \mathrm{g} \mathrm{C} \mathrm{L}$ in the high $\mathrm{CO}_{2}$ treatments until day 81 (Fig 4B). Afterwards, an increase in athecate dinoflagellates was observed until day 103 where values peaked at $8.92( \pm 3.38)$ at low and 23.25

$( \pm 12.01) \mu \mathrm{g} \mathrm{C} \mathrm{L}^{-1}$ at high $\mathrm{CO}_{2}$. Thecate dinoflagellates contributed only $\sim 2 \mu \mathrm{g} \mathrm{C} \mathrm{L}^{-1}$ on the last day. While biomass and diversity of dinoflagellates were not affected by the $\mathrm{CO}_{2}$ treatment, a positive effect of elevated $\mathrm{CO}_{2}$ on the total dinoflagellate abundance was found (p-value $<$ 0.001 , Table 1). When size classes were regarded separately, the effect was visible for dinoflagellate abundances from $30-55 \mu \mathrm{m}$ only (p-value $<0.001$ ).

Analysis of the biomass maxima and growth rates revealed no effect of $\mathrm{CO}_{2}$ on total ciliate biomass or ciliate taxa (Table 2). In contrast, the timing of the biomass maximum was significantly later in the high $\mathrm{CO}_{2}$ mesocosms for total ciliates $(\mathrm{p}$-value $=0.002)$ and Strombidium sp. $<40 \mu \mathrm{m}(\mathrm{p}$-value $=0.004)$.

Table 1. Results from the GAMM analysis.

\begin{tabular}{|c|c|c|c|c|}
\hline Variable & & $t$ & p-value & \\
\hline \multirow[t]{11}{*}{ Abundance } & log total phytoplankton & -2.626 & 0.010 & * \\
\hline & log phytoplankton $<8 \mu \mathrm{m}$ & -2.628 & 0.010 & * \\
\hline & log phytoplankton $>8 \mu \mathrm{m}$ & 0.937 & 0.351 & \\
\hline & log total ciliates & 0.542 & 0.589 & \\
\hline & log ciliates $<30 \mu \mathrm{m}$ & 0.704 & 0.483 & \\
\hline & log ciliates $30-55 \mu \mathrm{m}$ & -0.020 & 0.984 & \\
\hline & log ciliates $>55 \mu \mathrm{m}$ & 1.128 & 0.263 & \\
\hline & Total dinoflagellates & -26.490 & $<0.001$ & $* * *$ \\
\hline & log dinoflagellates $<30 \mu \mathrm{m}$ & -1.353 & 0.179 & \\
\hline & Dinoflagellates $30-55 \mu \mathrm{m}$ & -4.009 & $<0.001$ & $* * *$ \\
\hline & Dinoflagellates $>55 \mu \mathrm{m}$ & 0.315 & 0.754 & \\
\hline \multirow[t]{8}{*}{ Biomass } & log total ciliates & 0.945 & 0.347 & \\
\hline & log ciliates $<30 \mu \mathrm{m}$ & 0.519 & 0.605 & \\
\hline & log ciliates $30-55 \mu \mathrm{m}$ & -0.154 & 0.878 & \\
\hline & log ciliates >55 $\mu \mathrm{m}$ & 1.302 & 0.197 & \\
\hline & Total dinoflagellates & -1.872 & 0.064 & \\
\hline & Dinoflagellates $<30 \mu \mathrm{m}$ & -1.840 & 0.068 & \\
\hline & Dinoflagellates $30-55 \mu \mathrm{m}$ & -1.473 & 0.144 & \\
\hline & Dinoflagellates $>55 \mu \mathrm{m}$ & -0.365 & 0.716 & \\
\hline \multirow[t]{3}{*}{ Diversity index } & Phytoplankton $>8 \mu \mathrm{m}$ & -0.234 & 0.816 & \\
\hline & Ciliates & -0.264 & 0.792 & \\
\hline & Dinoflagellates & -0.857 & 0.393 & \\
\hline
\end{tabular}

Results from the GAMM analysis (Generalized Advanced Mixed Model) of the effects of high $\mathrm{CO}_{2}$ on phytoplankton and microzooplankton abundance, biomass, and diversity index. Significances are indicated by asterisks.

doi:10.1371/journal.pone.0165800.t001 

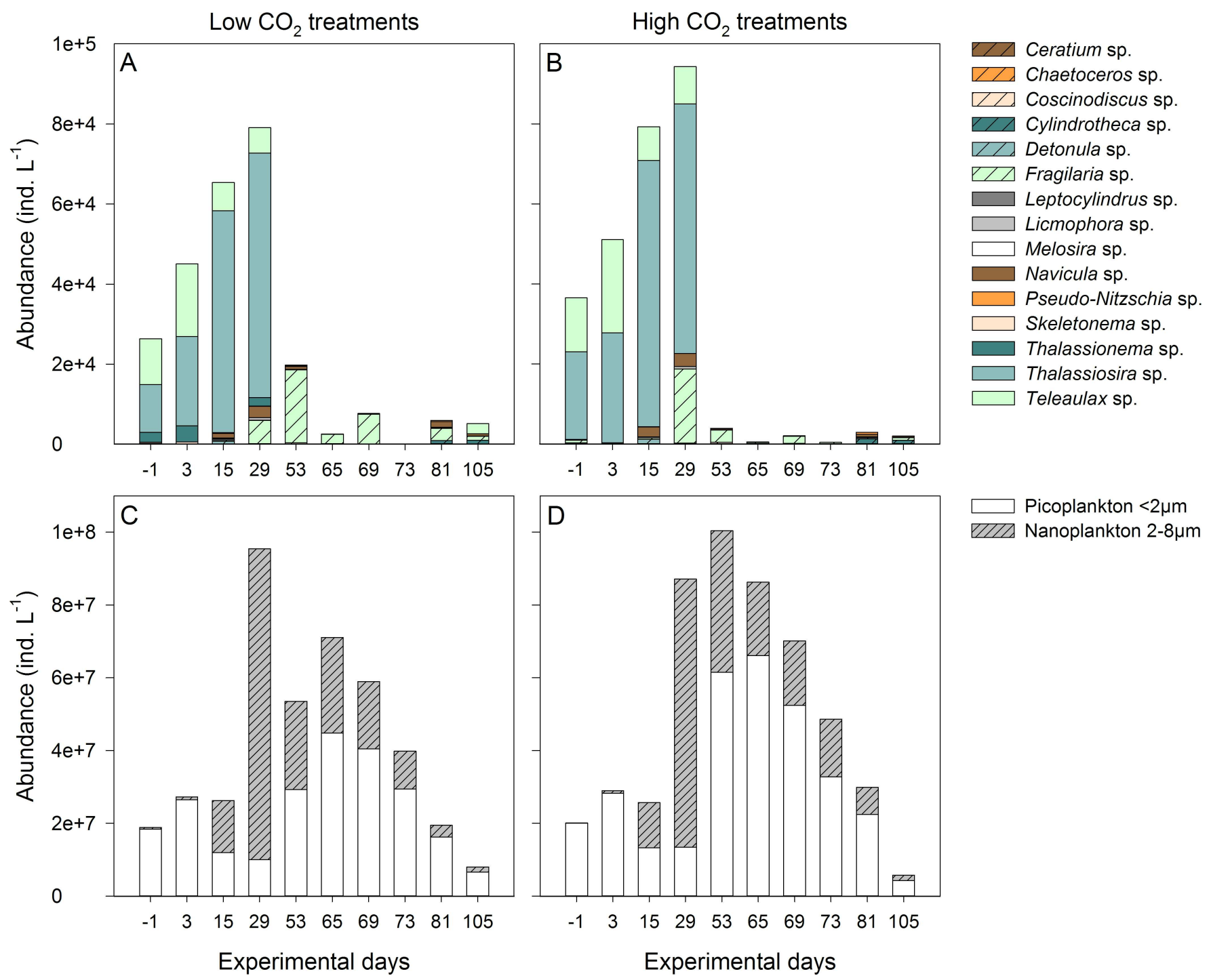

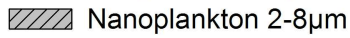

Fig 3. Phytoplankton community composition. Taxonomic composition of the phytoplankton size class $>8 \mu \mathrm{m}$ based on mean abundances from microscopic counts in the (A) low and (B) high $\mathrm{CO}_{2}$ treatments in ind. $\mathrm{L}^{-1}$ as well as abundances from the size classes $<8 \mu \mathrm{m}$ from flow cytometry in the (C) low and (D) high $\mathrm{CO}_{2}$ treatments.

doi:10.1371/journal.pone.0165800.g003

For athecate dinoflagellates $<30 \mu \mathrm{m}$, a positive effect of $\mathrm{CO}_{2}$ on the biomass maximum was observed ( $\mathrm{p}$-value $=0.028$ ) while thecate dinoflagellates and total dinoflagellate biomass were not affected. We also found a positive effect of high $\mathrm{CO}_{2}$ on the growth rates of total dinoflagellates ( $\mathrm{p}$-value $=0.043)$ and athecate dinoflagellates $<30 \mu \mathrm{m}(\mathrm{p}$-value $=0.007)$. There was no effect of $\mathrm{CO}_{2}$ on the timing of the biomass maxima $\mathrm{D}_{\max }$.

\subsection{MZP community composition}

The ciliate community was dominated by small Strombidium sp. $<40 \mu \mathrm{m}$ in both $\mathrm{CO}_{2}$ treatments, contributing up to $90 \%$ of the total biomass (Fig 5). On day 81 and 89 , Strombidium sp. $>40 \mu \mathrm{m}$ increased in biomass, providing about half of the total Strombidium sp. group. The cyclotrich Myrionecta rubra increased in abundance until day 25 where it contributed $18 \%$ in the low and $16 \%$ in high $\mathrm{CO}_{2}$ treatments. It was virtually absent from all mesocosms after day 
Table 2. Results for abundance and biomass maxima and growth rates.

\begin{tabular}{|c|c|c|c|c|c|c|}
\hline Variable & & Df & Mean Sq. & F value & p-value & \\
\hline \multirow[t]{3}{*}{ Abundance max. } & log total phytoplankton & 1 & 0.094 & 1.086 & 0.328 & \\
\hline & log phytoplankton $<8 \mu \mathrm{m}$ & 1 & 0.094 & 1.090 & 0.327 & \\
\hline & log phytoplankton $>8 \mu \mathrm{m}$ & 1 & 0.205 & 0.562 & 0.475 & \\
\hline \multirow[t]{17}{*}{ Biomass max. } & Total ciliates & 1 & 457.300 & 1.539 & 0.250 & \\
\hline & Strombidium sp. $<40 \mu \mathrm{m}$ & 1 & 0.112 & 0.324 & 0.585 & \\
\hline & Strombidium sp. $>40 \mu \mathrm{m}$ & 1 & 3.999 & 3.131 & 0.115 & \\
\hline & Strobilidium sp. & 1 & 0.774 & 0.882 & 0.375 & \\
\hline & Tontonia gracillima & 1 & 3.565 & 1.779 & 0.219 & \\
\hline & Laboea strobila & 1 & 0.720 & 0.340 & 0.578 & \\
\hline & Lohmaniella oviformis & 1 & 0.644 & 0.980 & 0.351 & \\
\hline & Myrionecta rubra & 1 & 0.018 & 0.238 & 0.639 & \\
\hline & Suctoria sp. & 1 & 0.332 & 0.440 & 0.528 & \\
\hline & Euplotes sp. & 1 & 0.015 & 2.180 & 0.178 & \\
\hline & Total dinoflagellates & 1 & 520.250 & 5.024 & 0.055 & \\
\hline & Thecate dinoflagellates $<30 \mu \mathrm{m}$ & 1 & 0.042 & 0.411 & 0.539 & \\
\hline & Thecate dinoflagellates $30-55 \mu \mathrm{m}$ & 1 & 0.298 & 0.170 & 0.691 & \\
\hline & Thecate dinoflagellates $>55 \mu \mathrm{m}$ & 1 & 0.589 & 2.564 & 0.148 & \\
\hline & Athecate dinoflagellates $<30 \mu \mathrm{m}$ & 1 & 1.663 & 7.137 & 0.028 & $*$ \\
\hline & Athecate dinoflagellates $30-55 \mu \mathrm{m}$ & 1 & 3.339 & 4.439 & 0.068 & \\
\hline & Athecate dinoflagellates $>55 \mu \mathrm{m}$ & 1 & 0.256 & 0.318 & 0.588 & \\
\hline \multirow[t]{12}{*}{ Growth rate } & Total phytoplankton & 1 & 0.304 & 3.260 & 0.109 & \\
\hline & Phytoplankton $>8 \mu \mathrm{m}$ & 1 & 0.176 & 0.427 & 0.532 & \\
\hline & Total ciliates & 1 & 0.345 & 1.448 & 0.263 & \\
\hline & Strombidium sp. $<40 \mu \mathrm{m}$ & 1 & 0.126 & 0.359 & 0.566 & \\
\hline & Strombidium sp. $>40 \mu \mathrm{m}$ & 1 & 1.727 & 1.627 & 0.243 & \\
\hline & Tontonia gracillima & 1 & 0.170 & 0.137 & 0.724 & \\
\hline & Laboea strobila & 1 & 0.041 & 0.028 & 0.873 & \\
\hline & Lohmaniella oviformis & 1 & 0.226 & 0.882 & 0.379 & \\
\hline & Total dinoflagellates & 1 & 1.586 & 5.807 & 0.043 & $*$ \\
\hline & Thecate dinoflagellates & 1 & 0.013 & 0.023 & 0.883 & \\
\hline & Athecate dinoflagellates $<30 \mu \mu \mathrm{m}$ & 1 & 3.127 & 12.821 & 0.007 & ** \\
\hline & Athecate dinoflagellates $30-55 \mu \mathrm{m}$ & 1 & 2.400 & 4.478 & 0.072 & \\
\hline \multirow[t]{8}{*}{$D_{\max }$} & Total ciliates & 1 & 2624.400 & 21.337 & 0.002 & ** \\
\hline & Strombidium sp. $<40 \mu \mathrm{m}$ & 1 & 3459.600 & 15.797 & 0.004 & ** \\
\hline & Strombidium sp. $>40 \mu \mathrm{m}$ & 1 & 144.400 & 0.224 & 0.649 & \\
\hline & Strobilidium sp. & 1 & 0.008 & 0.629 & 0.451 & \\
\hline & Tontonia gracillima & 1 & 0.075 & 1.084 & 0.328 & \\
\hline & Myrionecta rubra & 1 & 25.600 & 0.118 & 0.740 & \\
\hline & Thecate dinoflagellates $<30 \mu \mathrm{m}$ & 1 & 3027.600 & 3.125 & 0.115 & \\
\hline & Thecate dinoflagellates $>55 \mu \mathrm{m}$ & 1 & 48.400 & 0.074 & 0.793 & \\
\hline
\end{tabular}

Results from the ANOVAs of the effects of $\mathrm{CO}_{2}$ on abundance or biomass maximum (max.), growth rates, and timing of the maximum $\left(D_{\text {max }}\right)$ for phytoplankton, ciliates and dinoflagellates.

Significances are indicated by asterisks.

doi:10.1371/journal.pone.0165800.t002

49. In contrast, the choreotrich Lohmaniella oviformis formed a bloom between days 65 and 89 but was not found at other time points. The oligotrich group of Strobilidium sp. were present throughout the experiment in small numbers and formed a bloom around day 73, including 

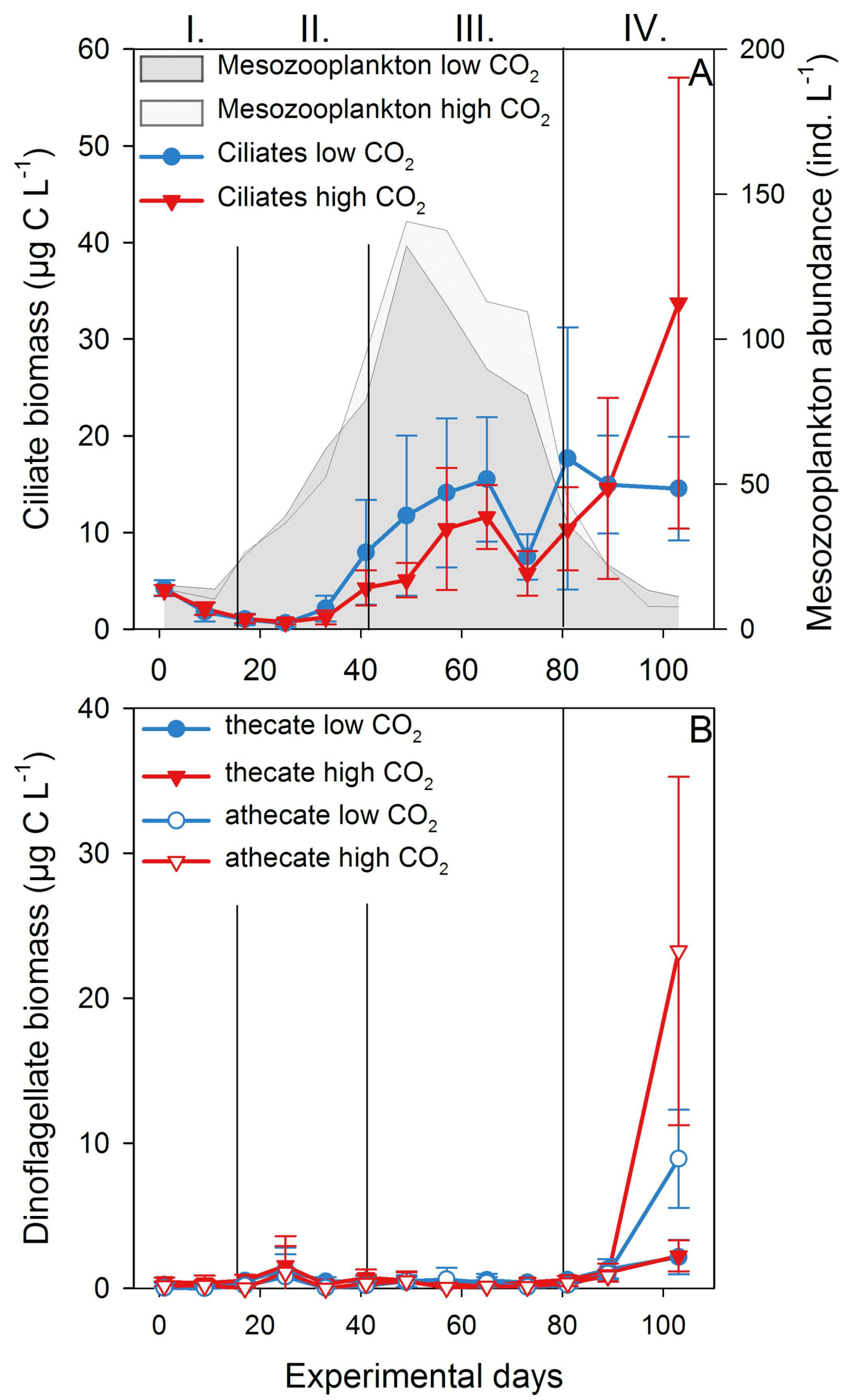
Fig 4. Microzooplankton succession. (A) Ciliate biomass in $\mu \mathrm{C} \mathrm{L}^{-1}$ in the low (blue) and high $\mathrm{CO}_{2}$ (red) treatments. Grey fields show total mesozooplankton abundance in ind. $\mathrm{L}^{-1}$ at low (dark grey) and high $\mathrm{CO}_{2}$ (light grey). Error bars represent the standard deviation and vertical black lines the four experimental phases denoted by the Latin numbers. (B) Biomass of thecate (filled symbols) and athecate dinoflagellates (open symbols) in $\mu \mathrm{g} \mathrm{CL}^{-1}$.

doi:10.1371/journal.pone.0165800.g004

large Rimostrombidium sp.. Large species such as Tontonia gracillima and Laboea strobila (size class $55-100 \mu \mathrm{m}$ ) were present throughout the experiment. The latter one reached high densities on the last day of the experiment, contributing $36 \%$ and $19 \%$ in the low and high $\mathrm{CO}_{2}$ treatments, respectively. Suctoria sp. was found almost exclusively on day 81 in both treatments, in similar densities. The group of rare species included Balanion comatum, Mesodinium pulex, Leegardiella sp., Tiarina fusus, Favella sp. and Acineta sp. in changing proportions at overall low concentrations.

Ciliate diversity was low at the start, increasing until day 33. After a sharp decrease around day 41 , caused by the peak of Strombidium sp. $<40 \mu \mathrm{m}$, it increased again afterwards. The diversity of the treatments was not significantly different (Table 1). Although the taxonomic composition of ciliates was very similar in both treatments; standard deviations between single mesocosms were high, especially in the high $\mathrm{CO}_{2}$ treatments at the end of the experiment.

During the first half of the experiment, the dinoflagellate community was dominated by thecate dinoflagellates, contributing up to $100 \%$ in both $\mathrm{CO}_{2}$ treatments (Fig 6). While the contribution of the different size classes varied over time, the main part of the size classes $>30 \mu \mathrm{m}$ was made up by different Protoperidinium sp. and Dinophysis sp., a mixotrophic taxon. Diversity was around 0.8 at the start and decreased in both treatments until day 49 . It increased during the second half of the experiment, starting on day 57 in the low $\mathrm{CO}_{2}$ and day 65 in the high $\mathrm{CO}_{2}$ treatments. This was due to an increase in athecate dinoflagellates, mainly large Gyrodinium sp. (size class $>55 \mu \mathrm{m}$ ). After a sharp decrease (low $\mathrm{CO}_{2}$ : day 65 , high $\mathrm{CO}_{2}$ : day 73), the contribution of athecate dinoflagellates increased again to almost $90 \%$ on day 103 . In this case, athecate taxa of the size classes $<30 \mu \mathrm{m}$ and $30-55 \mu \mathrm{m}$ each contributed about half

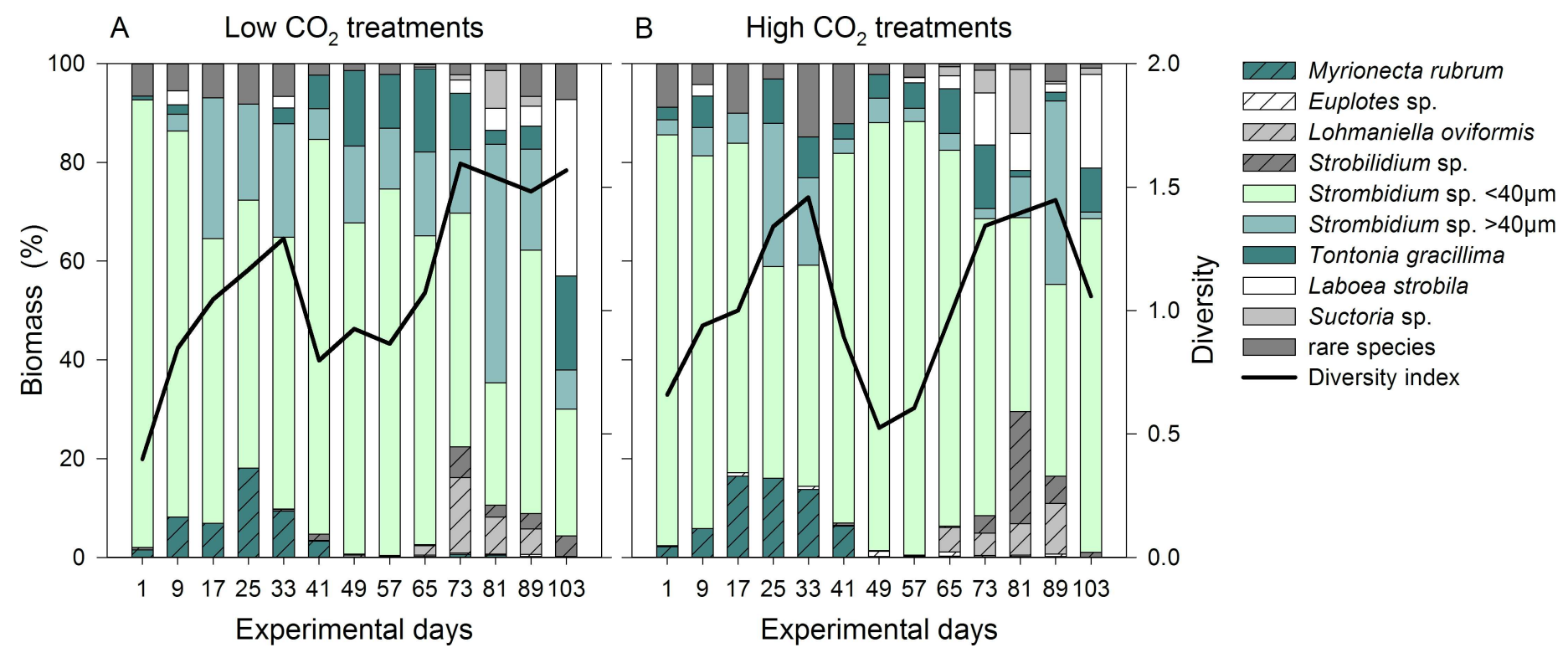

Fig 5. Ciliate community composition and diversity. Taxonomic composition of the ciliate community over the course of the experiment based on mean biomass of the $(A)$ low and $(B)$ high $\mathrm{CO}_{2}$ treatments. The black line indicates the species diversity $\mathrm{H}^{\prime}$.

doi:10.1371/journal.pone.0165800.g005 


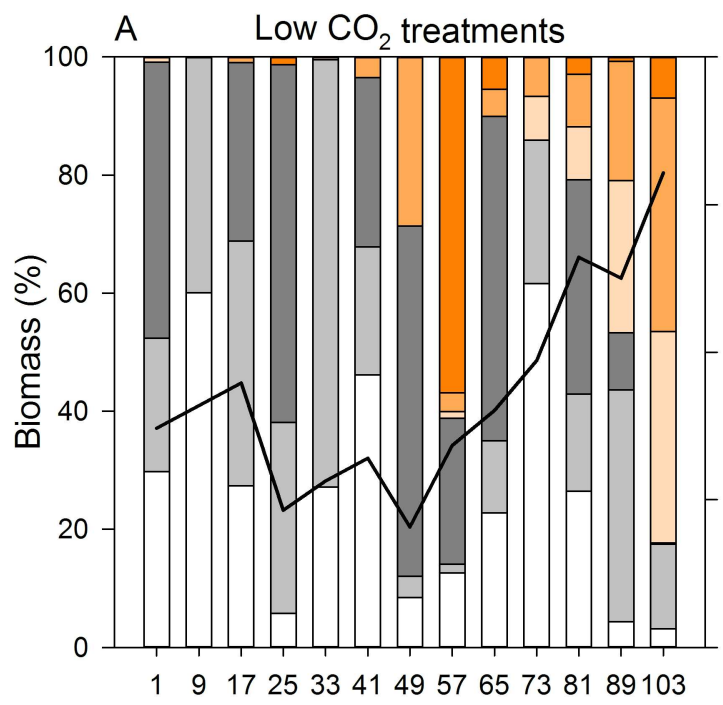

Experimental days
B High $\mathrm{CO}_{2}$ treatments

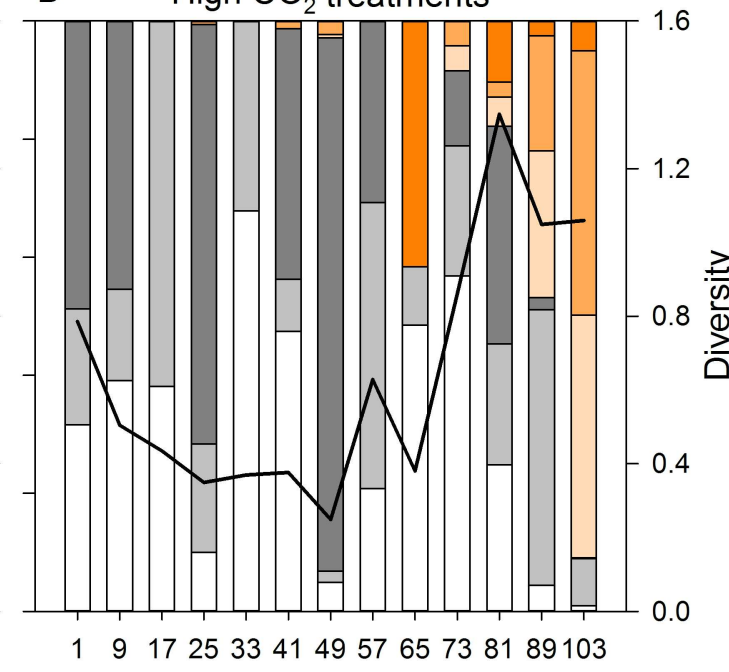

Experimental days

Fig 6. Dinoflagellate community composition and diversity. Size class composition of the thecate (grey bars) and athecate (orange bars) dinoflagellates for the size classes $<30 \mu \mathrm{m}, 30-55 \mu \mathrm{m}$ and $>55 \mu \mathrm{m}$ based on mean biomass of the $(\mathrm{A})$ low and $(\mathrm{B})$ high $\mathrm{CO}_{2}$ treatments.

Dinoflagellate diversity $\mathrm{H}^{\prime}$ is indicated by the black line.

doi:10.1371/journal.pone.0165800.g006

of the community while taxa $>55 \mu \mathrm{m}$ occurred in low numbers only. While this pattern was similar for both treatments, differences in biomass between single mesocosms increased towards the end of the experiment, most notably in the high $\mathrm{CO}_{2}$ treatments.

Overall, ciliates were the main player of the MZP community in terms of abundance and biomass, showing a similar succession pattern in the two $\mathrm{CO}_{2}$ treatments. They contributed $67-98 \%$ to the total MZP biomass with the exceptions of day 25 and 103 (Fig 7). On these two occasions, dinoflagellates made up $\sim 66 \%$ and $\sim 44 \%$, respectively.
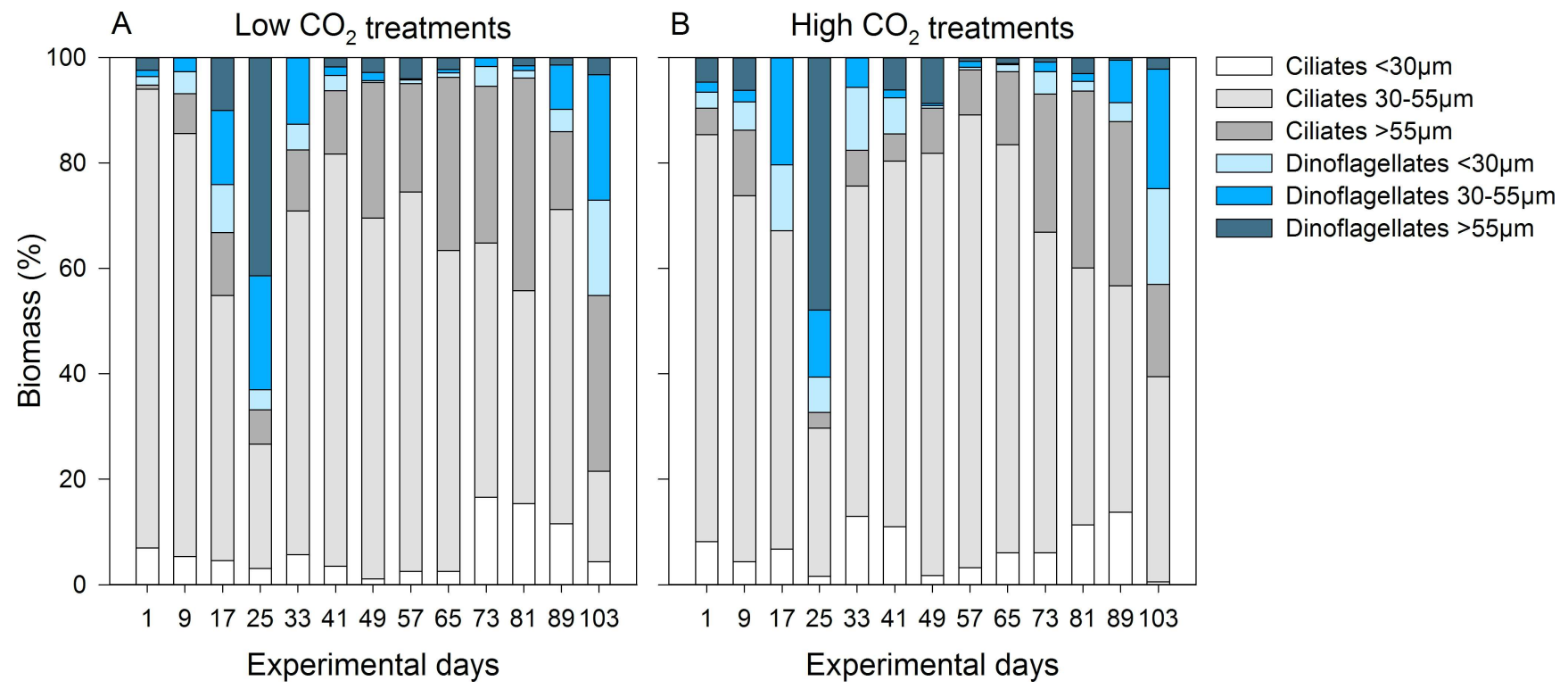

Fig 7. Microzooplankton community composition. Composition of ciliates (grey bars) and dinoflagellates (blue bars) for the size classes $<30 \mu \mathrm{m}, 30-55 \mu \mathrm{m}$ and $>55 \mu \mathrm{m}$ based on mean biomass of the (A) low and (B) high $\mathrm{CO}_{2}$ treatments.

doi:10.1371/journal.pone.0165800.g007 
Table 3. Results from the dilution experiment.

\begin{tabular}{|c|c|c|c|c|c|c|}
\hline Variable & & Df & Mean Sq & F value & p-value & \\
\hline \multirow[t]{5}{*}{$k$} & Total phytoplankton & 1 & 0.392 & 15.587 & 0.017 & $*$ \\
\hline & Flagellates $<5 \mu \mathrm{m}$ & 1 & 0.351 & 9.854 & 0.035 & $*$ \\
\hline & Flagellates $>5 \mu \mathrm{m}$ & 1 & 1.151 & 8.254 & 0.045 & $*$ \\
\hline & Dunaliella sp. & 1 & 2.211 & 6.718 & 0.061 & \\
\hline & Arcocellulus sp. & 1 & 0.049 & 0.046 & 0.840 & \\
\hline \multirow[t]{5}{*}{$m$} & Total phytoplankton & 1 & 1.281 & 37.078 & 0.004 & ** \\
\hline & Flagellates $<5 \mu \mathrm{m}$ & 1 & 1.494 & 57.024 & 0.002 & $* *$ \\
\hline & Flagellates $>5 \mu \mathrm{m}$ & 1 & 1.232 & 7.491 & 0.052 & \\
\hline & Dunaliella sp. & 1 & 1.413 & 7.278 & 0.054 & \\
\hline & Arcocellulus sp. & 1 & 0.550 & 0.562 & 0.495 & \\
\hline \multirow[t]{4}{*}{$\mu_{o}$} & Total phytoplankton & 1 & 2.333 & 34.348 & 0.004 & $* *$ \\
\hline & Flagellates $<5 \mu \mathrm{m}$ & 1 & 3.091 & 42.526 & 0.003 & $* *$ \\
\hline & Flagellates $>5 \mu \mathrm{m}$ & 1 & 0.865 & 1.363 & 0.308 & \\
\hline & Dunaliella sp. & 1 & 0.611 & 1.635 & 0.270 & \\
\hline
\end{tabular}

Results from the ANOVAs of the effects of $\mathrm{CO}_{2}$ on phytoplankton growth rate $k$, phytoplankton grazing mortality $m$ and instantaneous phytoplankton growth rate $\mu_{o}$ without nutrient addition from the dilution experiment.

Significances are indicated by asterisks. contributing to the community only during the last days.

\subsection{Grazing experiments}

For the dilution experiment conducted during the $1^{\text {st }}$ phytoplankton bloom peak, growth rates and natural growth rates could be calculated for the four most common phytoplankton groups as well as for total phytoplankton biomass (S1 Table). Phytoplankton growth rates $k$ were entirely negative with total phytoplankton, flagellates $<5 \mu \mathrm{m}$ and flagellates $>5 \mu \mathrm{m}$ declining significantly less in the high $\mathrm{CO}_{2}$ treatments (p-value $<0.05$, Table 3 ). Likewise, all instantaneous phytoplankton growth rates $\mu_{0}$ without nutrient addition were negative. However, they declined less under high $\mathrm{CO}_{2}$ conditions for total phytoplankton and flagellates $<5 \mu \mathrm{m}(\mathrm{p}$ value $<0.01$ ). Additionally, the actual phytoplankton grazing mortality $m$ was higher under high $\mathrm{CO}_{2}$ conditions for total phytoplankton and flagellates $<5 \mu \mathrm{m}$ ( $\mathrm{p}$-value $=0.002$ ) and close to significant for flagellates $>5 \mu \mathrm{m}$ ( $\mathrm{p}$-value $=0.052)$. We found no effect of $\mathrm{CO}_{2}$ on the chlorophyte Dunaliella sp. or the diatom Arcocellulus sp. for $k, m$ and $\mu_{0}$. Furthermore, the presence or absence of copepods had no effect on $k$ and $\mu_{o}$ (data not shown). MZP grazing rates $g$ were zero for almost all treatments and could not be further evaluated.

Analysis of the two community grazing experiments revealed no effect of $\mathrm{CO}_{2}$ concentration, grazer presence or an interaction of the two factors on net growth rates of total phytoplankton and ciliates (S2 and S3 Tables). There was also no effect on the most common phytoplankton taxa, Teleaulax sp., Arcocellulus sp., Paralia sulcata, flagellates $<5 \mu \mathrm{m}$ and flagellates $>5 \mu \mathrm{m}$ as well as the ciliates M. rubra, Strombidium sp. $<40 \mu \mathrm{m}$ and Strobilidium sp. $<30 \mu \mathrm{m}$. Dinoflagellate growth rates were also not affected in the $1^{\text {st }}$ experiment (Table 4 ).

However, during the $2^{\text {nd }}$ experiment, growth rates of thecate dinoflagellates $<30 \mu \mathrm{m}$ were significantly lower in the high $\mathrm{CO}_{2}$ treatment (p-value $=0.012$ ). 
Table 4. Results from the community grazing experiments.

\begin{tabular}{|c|c|c|c|c|c|c|c|}
\hline Experiment & Variable & Factor & Df & Mean Sq & F value & p-value & \\
\hline \multirow[t]{9}{*}{1} & Total dinoflagellates & $\mathrm{CO}_{2}$ & 1 & 0.216 & 0.452 & 0.511 & \\
\hline & & Grazer & 1 & 0.596 & 1.249 & 0.280 & \\
\hline & & $\mathrm{CO}_{2} \times$ Grazer & 1 & 0.064 & 0.134 & 0.719 & \\
\hline & Thecate dinos $<30 \mu \mathrm{m}$ & $\mathrm{CO}_{2}$ & 1 & 0.530 & 0.558 & 0.466 & \\
\hline & & Grazer & 1 & 0.014 & 0.015 & 0.904 & \\
\hline & & $\mathrm{CO}_{2} \times$ Grazer & 1 & 0.504 & 0.531 & 0.477 & \\
\hline & Thecate dinos $>30 \mu \mathrm{m}$ & $\mathrm{CO}_{2}$ & 1 & 0.150 & 0.123 & 0.731 & \\
\hline & & Grazer & 1 & 1.812 & 1.490 & 0.242 & \\
\hline & & $\mathrm{CO}_{2} \times$ Grazer & 1 & 0.038 & 0.031 & 0.863 & \\
\hline \multirow[t]{6}{*}{$\underline{2}$} & Total dinoflagellates & $\mathrm{CO}_{2}$ & 1 & 0.001 & 0.000 & 0.984 & \\
\hline & & Grazer & 1 & 0.738 & 0.324 & 0.577 & \\
\hline & & $\mathrm{CO}_{2} \times$ Grazer & 1 & 0.343 & 0.150 & 0.703 & \\
\hline & Thecate dinos $<30 \mu \mathrm{m}$ & $\mathrm{CO}_{2}$ & 1 & 6.734 & 8.659 & 0.012 & $*$ \\
\hline & & Grazer & 1 & 0.401 & 0.515 & 0.487 & \\
\hline & & $\mathrm{CO}_{2} \times$ Grazer & 1 & 0.713 & 0.917 & 0.357 & \\
\hline
\end{tabular}

Results from the ANOVAs of the effects of $\mathrm{CO}_{2}$, grazer presence, and the interaction of the two factors on growth rate of total dinoflagellates and the two size classes of thecate dinoflagellates (dinos) in the community grazing experiments. Significances are indicated by asterisks.

doi:10.1371/journal.pone.0165800.t004

\section{Discussion}

The mesocosms were sustained for more than 100 days by counteracting problems occurring during long-term studies with extensive maintenance work, such as regular cleaning of the inand outside of the mesocosms to avoid wall growth. While there were fluctuations of $p \mathrm{CO}_{2}$ for the ambient and the high $\mathrm{CO}_{2}$ treatments over time due to photosynthetic carbon fixation and outgassing, there was no overlap between treatments at any time point.

The abundances of MZP in the mesocosms ranged from 4320 to 7489 ind. $\mathrm{L}^{-1}$ at the start point which is within the expected range for the Gullmar Fjord area in the beginning of March [42]. MZP abundance stayed comparatively low during the experiment, with the exception of the post-bloom phase for both dinoflagellates and ciliates. Overall, the observed effects of elvated $\mathrm{CO}_{2}$ concentrations on the measured MZP parameters were comparatively small and subtle.

\subsection{Effects on phytoplankton}

While some phytoplankton groups like calcifying algae are negatively affected by OA [43, 44], a fertilizing effect on other groups due to the increased availability of carbon has been observed $[9,45,46]$. For example for diatoms, a shift in species composition has been found in different field studies [17] and also changes on genetic level have been observed in laboratory experiments [47]. Comparable to other studies using this mobile mesocosm system, the composition of phytoplankton and the development of abiotic factors such as light and temperature during a spring-bloom situation mimic the natural situation to a high degree. While a $1^{\text {st }}$ bloom peak in the fjord was reached on day 27 with $\mathrm{Chl} a$ concentrations of $3.52 \mu \mathrm{g} \mathrm{L}{ }^{-1}$, the mesocosm bloom peaked on day 29 in the low and day 33 in the high $\mathrm{CO}_{2}$ mesocosms at 4.04 and $4.49 \mu \mathrm{g}$ $\mathrm{L}^{-1}$, respectively.

According to the GAMM analysis, Chl a concentrations were significantly higher at high $\mathrm{CO}_{2}$ even though the effect seemed to be most pronounced in phase III around the $2^{\text {nd }}$ phytoplankton bloom peak (Fig 2A). We found no effect of high $\mathrm{CO}_{2}$ on the abundance of 
phytoplankton $>8 \mu \mathrm{m}$. Nonetheless, considering abundances, large sized phytoplankton played only a minor role during both phytoplankton bloom phases. Based on previous studies from other regions, a positive $\mathrm{CO}_{2}$ effect on pico- and nanoeukaryotes is more likely to occur $[18,19]$. In fact, a positive effect of a high $\mathrm{CO}_{2}$ level on picophytoplankton was observed in this experiment [28] which could explain the higher $\mathrm{Chl} a$ concentrations in these treatments to some extent.

\subsection{Effects on MZP community composition}

A direct effect of a lowered $\mathrm{pH}$ on MZP has been shown for areas such as the Baltic Sea or the North Atlantic [11, 12], visible e.g. in the inhibition of growth [10]. However, these effects were only shown for extreme $\mathrm{pH}$ values that are unlikely to occur in the near future [10]. Results from a laboratory study applying more realistic OA scenarios on a single MZP species showed no direct effect [13]. In support of that, most mesocosm studies with a $\mathrm{CO}_{2}$ level expected for the end of the $21^{\text {st }}$ century also show no or only subtle effects on the MZP community composition and diversity $[15,23,24]$. This can be partly attributed to the high tolerance of coastal communities to frequently occurring habitat $\mathrm{pH}$ fluctuations [48, 49]. In general, open ocean communities are considered to be more susceptible to OA as they do not experience these fluctuations, still Rose et al. [14] reported no direct effects of an elevated $\mathrm{CO}_{2}$ level on the MZP community in a study in the open Atlantic Ocean.

The aforementioned mesocosm studies lasted 14 to 41 days. Nonetheless, even the longer runtime of 113 days in our study did not result in an effect of the applied $\mathrm{CO}_{2}$ level on the MZP community composition and diversity. Thus, hypothesis (1) stating that an elevated $\mathrm{CO}_{2}$ level will not directly affect MZP communities due to their high $\mathrm{CO}_{2}$ tolerance could not be rejected. In fact, there was an almost parallel development of the composition over time in the two treatments, both for ciliates and heterotrophic dinoflagellates.

\subsection{Effects on MZP biomass and growth rates}

For autotrophic phytoplankton, it has already been shown that high $\mathrm{CO}_{2}$ can have an either positive or negative direct impact, depending on the plankton group in focus [16, 20]. In contrast, indirect effects are considered to be more important for heterotrophic or mixotrophic zooplankton than direct ones, such as changes in phytoplankton availability or food quality $[14,50,51]$.

Generally, effects of $\mathrm{CO}_{2}$ are likely to be more intense in a nutrient-deplete system than in a nutrient-replete one $[18,28,52]$ even though this is not always the case, as e.g. in the Arctic Ocean [53]. Nutrient concentrations in the mesocosms were high in the beginning, caused by entrapping nutrient-rich deep water in the mesocosms which is distributed through the whole water column due to wind-induced mixing during wintertime [54]. Nutrient depletion occurred already during the $1^{\text {st }}$ phytoplankton bloom/phase II resulting in the $2^{\text {nd }}$ phytoplankton bloom/phase III being nutrient-deplete and nutrients such as $\mathrm{NO}_{3}{ }^{-} / \mathrm{NO}_{2}{ }^{-}, \mathrm{Si}(\mathrm{OH})_{4}$ and $\mathrm{PO}_{4}{ }^{3-}$ being at concentrations close to or below detection limit [28]. In conclusion, nutrients must have been provided by remineralization to support the observed $2^{\text {nd }}$ bloom, but were immediately used up and thus did not accumulate in the nutrient pool.

While community composition of large phytoplankton was not affected by $\mathrm{CO}_{2}$ in the data set we analyzed, positive effects on picoeukaryotes were observed [28]. Additionally, we found a positive effect of high $\mathrm{CO}_{2}$ on the abundances of heterotrophic dinoflagellates over time.

Total biomass, however, was not affected. This is in agreement with biomass maximum and growth rates of small athecate dinoflagellates $<30 \mu \mathrm{m}$ being higher at elevated $\mathrm{CO}_{2}$. The dominance of small athecate dinoflagellates in the community was most likely also the reason why a 
positive $\mathrm{CO}_{2}$ effect on the total dinoflagellate growth rate was found despite of the other size classes not being affected by $\mathrm{CO}_{2}$ (Fig 7). Thus, not only phytoplankton but also smaller size classes of microzooplankton seemed to benefit from an elevated $\mathrm{CO}_{2}$ level.

A high contribution of athecate dinoflagellates to the total MZP community during the bloom or in the post-bloom phase as in our case has been described for several coastal areas [55]. In contrast, total ciliate biomass was lower under high $\mathrm{CO}_{2}$ conditions during the $2^{\text {nd }}$ bloom, even though this effect was not significant. Overall, abundances of large phytoplankton and copepods (Algueró-Muñiz, unpublished data) were not significantly affected by the $\mathrm{CO}_{2}$ level in this phase. Still, abundance of pico- and nanophytoplankton was higher at high $\mathrm{CO}_{2}$ so the negative effect on MZP was probably caused by additional factors.

The dilution experiment conducted right after the $1^{\text {st }}$ bloom peak took place at a time when MZP abundances were still low. Considering that the phytoplankton community composition was not different from the regular samples from the mesocosms, we can assume that there was no loss of any groups from handling the water samples. The overall decline of phytoplankton was most probably caused by senescence as nutrient addition prevented limitation and the MZP grazing impact was low due to low MZP abundances.

Nonetheless, there was an indication of a higher phytoplankton biomass at high $\mathrm{CO}_{2}$ in the dilution experiment as we observed instantaneous phytoplankton growth rates $\mu_{0}$ declining less in the high $\mathrm{CO}_{2}$ treatments. As $\mu_{0}$ is calculated without the grazing impact, the results suggest that phytoplankton was indeed growing better under high $\mathrm{CO}_{2}$, especially small flagellates. This would also fit to $\mathrm{Chl} a$ maximum of the $1^{\text {st }}$ phytoplankton peak being higher at high $\mathrm{CO}_{2}$ and has been described by other authors [16-19]. We also observed an overall higher phytoplankton grazing mortality $m$ in the high $\mathrm{CO}_{2}$ treatments pointing at a higher MZP abundance at high $\mathrm{CO}_{2}$ even though actual grazing rates could not be calculated. This is mirrored in the phytoplankton growth rates $k$ declining more at high $\mathrm{CO}_{2}$ due to the MZP grazing impact.

Although the two community grazing experiments took place during the $1^{\text {st }}$ and $2^{\text {nd }}$ bloom peak, thus consisting of two somewhat different phytoplankton communities, MZP communities and MZP biomass, the result was the same for both phytoplankton and ciliate growth rates which were not affected by $\mathrm{CO}_{2}$. The lack of effect of the grazer treatment for the aforementioned parameters was most likely based on the reduced copepod abundances in the incubation bottles in comparison the mesocosms. Contrastingly, there was once more an effect on dinoflagellates during the $2^{\text {nd }}$ bloom, but in this case a negative $\mathrm{CO}_{2}$ effect on the growth rates of heterotrophic thecate dinoflagellates of the size class $<30 \mu \mathrm{m}$. In addition, we once more found an indication for higher phytoplankton abundances at high $\mathrm{CO}_{2}$ in the community grazing experiments which could potentially lead to an increase in MZP biomass. An increase in MZP biomass was indeed what we observed in the mesocosms on day 103 when grazing pressure by copepods had all but disappeared.

We hypothesized that (2) an increase in phytoplankton biomass at high $\mathrm{CO}_{2}$ conditions due to positive effects on photosynthesis will lead to enhanced MZP biomass and grazing rates. While grazing rates could not be calculated, hypothesis (2) was confirmed with regard to biomass of dinoflagellates of the size class $30-55 \mu \mathrm{m}$ as we did observe effects of an elevated $\mathrm{CO}_{2}$ level, even though most phytoplankton groups were not affected. However, the hypothesis was rejected for ciliates as this group showed no response except for a delayed bloom peak under high $\mathrm{CO}_{2}$.

\subsection{Food web effects}

While an increase in phytoplankton has the potential to positively influence MZP, the effect might be masked by grazing pressure by mesozooplankton as a numerical response of 
copepods to increasing MZP densities has been described [56]. As mentioned before, copepods are known to be size-selective in their feeding behavior, and while ciliates have the ideal size, phytoplankton cells are often either too small or too large [57]. In our experiment, phytoplankton $<8 \mu \mathrm{m}$ contributed almost $99 \%$ of the phytoplankton community during the two blooms in terms of abundance. In general, this size class is considered inedible for most copepod species but represents ideal food items for MZP, especially ciliates [58]. It has already been shown in other experiments that nanoflagellates are selectively grazed upon by ciliates even if other phytoplankton groups are present in sufficient densities [5]. In contrast, dinoflagellates can consume phytoplankton cells larger than their own size and also cannibalistic feeding behavior has been reported [59].

Noticeable was the appearance of large Coscinodiscus sp. $(>200 \mu \mathrm{m})$ during the two phytoplankton blooms, reaching abundances of $\sim 428$ ind. $\mathrm{L}^{-1}$ during the $2^{\text {nd }}$ bloom and contributing to a large part of the total phytoplankton biomass. However, this large-sized diatom is usually not considered as a copepod food source, even though some copepod species have been reported to feed on them [60]. In conclusion, there was hardly any phytoplankton present in a size class edible for mesozooplankton despite of high phytoplankton abundances during the bloom phases. The low concentration of MZP was therefore most likely caused by intense topdown control by mesozooplankton, thus MZP functioned as a "trophic link" between different levels of the present food web [8].

In addition, grazing pressure could also explain the trend towards higher MZP biomass at high $p \mathrm{CO}_{2}$ as observed during the post-bloom phase (IV), despite deviations between mesocosms being high. The MZP succession pattern fits to the development of the mesozooplankton population in both $\mathrm{CO}_{2}$ treatments ( $\mathrm{Fig} 4 \mathrm{~A}$ ). Starting at low initial abundances, total mesozooplankton increased in numbers reaching on average 136 ind. $\mathrm{L}^{-1}( \pm 23)$ on day 49 . The dominating mesozooplankton group was copepods, most notably Pseudocalanus acuspes. By the end of the $2^{\text {nd }}$ bloom mesozooplankton was reduced to $\sim 40$ ind. $\mathrm{L}^{-1}$, and continued decreasing even more, thus releasing the MZP from grazing pressure (details on mesozooplankton presented by Algueró-Muñiz, unpublished data). This was the time point when ciliates and dinoflagellates started to increase in the high $\mathrm{CO}_{2}$ treatments, despite the decline in phytoplankton densities. While MZP, and especially dinoflagellates, show a variety of feeding mechanisms [55], most taxa are considered as mixotroph and do not necessarily rely on high phytoplankton concentrations alone.

Finally, the occurrence of fish larvae as top-predators of the system had the potential to reduce both copepod and MZP densities. The herring larvae which were released into the mesocosms on day 63 could explain the drop in biomass observed for ciliates on day 73 (Fig 4A) as early stage larval fish are known to feed on MZP [61]. Around day 71, the larvae should have been at an age when they switch from yolk-sack stage to feeding on nauplii and large MZP $(>55 \mu \mathrm{m})$ [62]. Consequently, large ciliates increased in abundance again afterwards, at the point when the fish larvae started feeding on larger food items such as copepods thus releasing the MZP from grazing pressure. The effect was not visible for large dinoflagellates, probably due to their overall low numbers at this time point.

Apart from grazing pressure by copepods, an explanation for the low MZP biomass at the beginning of the experiment and the lack of response to the $1^{\text {st }}$ phytoplankton bloom (Fig $4 \mathrm{~A}$ ) could have been the low temperatures. In contrast to phytoplankton, which is in large parts light-dependent due to photosynthesis, MZP shows a temperature-dependence due to the biochemical processes of its metabolism [63]. Therefore, a relationship between an increase in temperature and an increase in production has been observed [64-66]. At the beginning of this experiment, sea surface temperatures were $\sim 1^{\circ} \mathrm{C}$ and during the $1^{\text {st }}$ phytoplankton bloom phase $\sim 5^{\circ} \mathrm{C}$ (Fig 1). The low temperature seemed to prevent MZP from growth as no biomass 
increase was observed in response to increases in phytoplankton standing stock. Only during the $2^{\text {nd }}$ phytoplankton bloom phase when temperatures reached up to $10^{\circ} \mathrm{C}$, a biomass peak in MZP was observed.

Hypothesis (3) predicted that small sized phytoplankton will profit from high $\mathrm{CO}_{2}$ levels which is in favor of MZP, but not mesozooplankton. Overall, it was accepted as an alteration of the phytoplankton community was observed in favor of small-sized phytoplankton. Moreover, as MZP most likely made use of the increase in small phytoplankton while simultaneously being a preferred food item for copepods, the hypothesized increased grazing pressure on MZP due to high $\mathrm{CO}_{2}$ was observed.

\subsection{Conclusion}

Complex near-natural systems like the one used in this mesocosms study are associated with a higher buffering capacity towards the effects of $\mathrm{OA}$ in comparison with lab studies using simplified food webs [24]. Nevertheless, while we found a high tolerance of most MZP groups to a realistic acidification scenario, we observed effects on both phytoplankton and MZP. While large phytoplankton species remained unaffected by high $\mathrm{CO}_{2}$, abundances of small taxa and $\mathrm{Chl} a$ concentrations were positively affected. We observed no effects on ciliates apart from a delayed bloom peak under high $\mathrm{CO}_{2}$. There was, however, a positive effect of $\mathrm{CO}_{2}$ on heterotrophic dinoflagellate abundances as well as the biomass maximum and growth rate of athecate dinoflagellates $(<30 \mu \mathrm{m})$.

This highlights the importance of long-term studies lasting for a complete succession period to follow e.g. an entire build-up and decline during bloom periods in spring. Previous mesocosm studies of comparable size from the Baltic Sea, the North Sea and the Arctic considered only shorter time spans. This might have masked effects of high $\mathrm{CO}_{2}$ which are visible only under long-term exposure [15, 23, 24, 67]. Based on the results, MZP communities from coastal regions comparable to the study site are not expected to be strongly affected by end-ofcentury $\mathrm{CO}_{2}$ levels.

\section{Supporting Information}

S1 Table. Results from the dilution experiment. Mean values and standard error (Std.error) of the phytoplankton growth rate $k$, instantaneous (natural) phytoplankton growth rate $\mu_{0}$, phytoplankton mortality $m$ and microzooplankton grazing rate $g$ are shown for the different phytoplankton groups distinguished in the dilution experiment.

(DOCX)

S2 Table. Results from the community grazing experiments. Mean values and standard error (Std.error) of the net growth rates calculated for the most abundant groups of phytoplankton, ciliates and dinoflagellates (dinos) in experiment (Exp.) 1 and 2. The four treatments used were low $\mathrm{CO}_{2}$ without grazer (Low -G), low $\mathrm{CO}_{2}$ with grazer (Low $+\mathrm{G}$ ), high $\mathrm{CO}_{2}$ without grazer (High $-\mathrm{G})$, and high $\mathrm{CO}_{2}$ with grazer $(\mathrm{High}+\mathrm{G})$.

(DOCX)

S3 Table. Results from the analysis of the community grazing experiments. Results from the ANOVAs from the two community grazing experiments. Effects of $\mathrm{CO}_{2}$, grazer presence (Grazer), and the interaction of the two factors on growth rate of total phytoplankton and ciliates as well as the most common taxa of the two groups are shown. Transformations are indicated.

(DOCX) 


\section{Acknowledgments}

This study is part of the German Federal Ministry of Science and Education (BMBF) funded "Verbundprojekt" BIOACID Phase II (Biological Impacts of Ocean ACIDification), consortium 1, WP 1.6 (03F0655B) and received funding from the Swedish Academy of Sciences. We gratefully acknowledge the Sven Lovén Centre for Marine Sciences, University of Gothenburg, for accommodation and on-site logistic support. We also thank the captain and crew of R/V Alkor for assistance during transport, deployment and recovery of the mesocosms. The Kristineberg KOSMOS 2013 Consortium is acknowledged for the help with mesocosm maintenance and sampling. S. Peters, K. Carstens and S. Ohse are additionally acknowledged for their technical support and S. Frickenhaus for assistance with statistical analysis.

\section{Author Contributions}

Conceptualization: NA MB MGJL HGH UR.

Data curation: HGH MAM LTB AS.

Formal analysis: HGH MAM LTB AS NS.

Funding acquisition: NA UR.

Investigation: HGH MAM LTB AS NS.

Methodology: HGH NA MB MGJL MAM.

Project administration: NAM MB UR.

Resources: HGH NA MB UR LTB MGJL MAM AS.

Supervision: NA MB MGJL UR.

Validation: HGH MAM LTB.

Visualization: $\mathrm{HGH}$.

Writing - original draft: $\mathrm{HGH}$.

Writing - review \& editing: HGH NA MB UR LTB MGJL MAM AS NS.

\section{References}

1. Le Quéré C, Andres RJ, Boden T, Conway T, Houghton RA, House Jl, et al. The global carbon budget 1959-2011. Earth System Science Data. 2013; 5(1):165-85.

2. Collins $M$, Knutti R, Arblaster J, Dufresne J-L, Fichefet T, Friedlingstein $P$, et al. Long-term Climate Change: Projections, Commitments and Irreversibility. In: Climate Change 2013: The Physical Science Basis. Contribution of Working Group I to the Fifth Assessment Report of the Intergovernmental Panel on Climate Change [Stocker T.F., Qin D., Plattner G.-K., Tignor M., Allen S.K., Boschung J., Nauels A., Xia Y., Bex V. and Midgley P.M. (eds.)]. Cambridge, United Kingdom and New York, NY, USA: Cambridge University Press; 2013. 1552 p.

3. Sabine CL, Feely RA, Gruber N, Key RM, Lee K, Bullister JL, et al. The oceanic sink for anthropogenic $\mathrm{CO}_{2}$. Science. 2004; 305(5682):367-71. doi: 10.1126/science.1097403 PMID: 15256665

4. Ciais P, Sabine C, Bala G, Bopp L, Brovkin V, Canadell J, et al. Carbon and Other Biogeochemical Cycles. In: Climate Change 2013: The Physical Science Basis. Contribution of Working Group I to the Fifth Assessment Report of the Intergovernmental Panel on Climate Change [Stocker T.F., Qin D., Plattner G.-K., Tignor M., Allen S.K., Boschung J., Nauels A., Xia Y., Bex V. and Midgley P.M. (eds.)]. Cambridge, United Kingdom and New York, NY, USA: Cambridge University Press; 2013. 1552 p.

5. Löder MGJ, Meunier C, Wiltshire KH, Boersma M, Aberle N. The role of ciliates, heterotrophic dinoflagellates and copepods in structuring spring plankton communities at Helgoland Roads, North Sea. Mar Biol. 2011; 158(7):1551-80. 
6. Calbet A, Landry MR. Phytoplankton growth, microzooplankton grazing, and carbon cycling in marine systems. Limnol Oceanogr. 2004; 49(1):51-7.

7. Aberle N, Lengfellner K, Sommer U. Spring bloom succession, grazing impact and herbivore selectivity of ciliate communities in response to winter warming. Oecologia. 2007; 150(4):668-81. doi: 10.1007/ s00442-006-0540-y PMID: 16964503

8. Calbet A, Saiz E. The ciliate-copepod link in marine ecosystems. Aquat Microb Ecol. 2005; 38(2):15767.

9. Riebesell U, Schulz KG, Bellerby RGJ, Botros M, Fritsche P, Meyerhofer M, et al. Enhanced biological carbon consumption in a high $\mathrm{CO}_{2}$ ocean. Nature. 2007; 450(7169):545-U10. doi: 10.1038/ nature06267 PMID: 17994008

10. Nielsen LT, Jakobsen HH, Hansen PJ. High resilience of two coastal plankton communities to twentyfirst century seawater acidification: Evidence from microcosm studies. Mar Biol Res. 2010; 6(6):54255.

11. Hinga KR. Co-occurrence of dinoflagellate blooms and high $\mathrm{pH}$ in marine enclosures. Mar Ecol-Prog Ser. 1992; 86(2):181-7.

12. Pedersen MF, Hansen PJ. Effects of high $\mathrm{pH}$ on a natural marine planktonic community. Mar Ecol-Prog Ser. 2003; 260:19-31.

13. Meunier CL, Algueró-Muniz M, Horn HG, Lange JAF, Boersma M. Direct and indirect impact of nearfuture $p \mathrm{CO}_{2}$ levels on zooplankton dynamics. Mar Freshw Res. 2016.

14. Rose JM, Feng Y, Gobler CJ, Gutierrez R, Hare CE, Leblanc K, et al. Effects of increased $\mathrm{pCO}_{2}$ and temperature on the North Atlantic spring bloom. II. Microzooplankton abundance and grazing. Mar Ecol-Prog Ser. 2009; 388:27-40.

15. Calbet A, Sazhin AF, Nejstgaard JC, Berger SA, Tait ZS, Olmos L, et al. Future Climate Scenarios for a Coastal Productive Planktonic Food Web Resulting in Microplankton Phenology Changes and Decreased Trophic Transfer Efficiency. PloS one. 2014; 9(4):e94388. doi: 10.1371/journal.pone. 0094388 PMID: 24721992

16. Low-Decarie E, Fussmann GF, Bell G. Aquatic primary production in a high- $\mathrm{CO}_{2}$ world. Trends Ecol Evol. 2014; 29(4):223-32. doi: 10.1016/j.tree.2014.02.006 PMID: 24631287

17. Rost B, Zondervan I, Wolf-Gladrow D. Sensitivity of phytoplankton to future changes in ocean carbonate chemistry: current knowledge, contradictions and research directions. Mar Ecol-Prog Ser. 2008; 373:227-37.

18. Sala MM, Aparicio FL, Balagué V, Bora JA, Borrull E, Cardelús $C$, et al. Contrasting effects of ocean acidification on the microbial food web under different trophic conditions. ICES J Mar Sci. 2016; 73 (3):670-9.

19. Brussaard CPD, Noordeloos AAM, Witte H, Collenteur MCJ, Schulz KG, Ludwig A, et al. Arctic microbial community dynamics influenced by elevated $\mathrm{CO}_{2}$ levels. Biogeosciences. 2013; 10(2):719-31.

20. Kroeker KJ, Kordas RL, Crim R, Hendriks IE, Ramajo L, Singh GS, et al. Impacts of ocean acidification on marine organisms: quantifying sensitivities and interaction with warming. Glob Chang Biol. 2013; 19 (6):1884-96. doi: 10.1111/gcb.12179 PMID: 23505245

21. Caron DA, Hutchins DA. The effects of changing climate on microzooplankton grazing and community structure: drivers, predictions and knowledge gaps. J Plankton Res. 2012; 35(2):235-52.

22. Rossoll D, Sommer U, Winder M. Community interactions dampen acidification effects in a coastal plankton system. Mar Ecol-Prog Ser. 2013; 486:37-46.

23. Aberle N, Schulz KG, Stuhr A, Malzahn AM, Ludwig A, Riebesell U. High tolerance of microzooplankton to ocean acidification in an Arctic coastal plankton community. Biogeosciences. 2013; 10(3):1471-81.

24. Suffrian K, Simonelli P, Nejstgaard JC, Putzeys S, Carotenuto Y, Antia AN. Microzooplankton grazing and phytoplankton growth in marine mesocosms with increased $\mathrm{CO}_{2}$ levels. Biogeosciences. 2008; 5 (4):1145-56.

25. Horn HG, Boersma M, Garzke J, Löder MGJ, Sommer U, Aberle N. Effects of high $\mathrm{CO}_{2}$ and warming on a Baltic Sea microzooplankton community. ICES J Mar Sci. 2016; 73(3):772-82.

26. Lohbeck KT, Riebesell U, Reusch TBH. Adaptive evolution of a key phytoplankton species to ocean acidification. Nat Geosci. 2012; 5(5):346-51.

27. Riebesell U, Czerny J, von Bröckel K, Boxhammer T, Büdenbender J, Deckelnick M, et al. Technical Note: A mobile sea-going mesocosm system-new opportunities for ocean change research. Biogeosciences. 2013; 10(3):1835-47.

28. Bach LT, Taucher J, Boxhammer T, Ludwig A, The Kristineberg KOSMOS Consortium, Achterberg E., et al. Influence of ocean acidification on a natural winter-to-summer plankton succession: First insights from a long-term mesocosm study draw attention to periods of nutrient limitation. PloS one. accepted. 
29. Utermöhl H. Zur Vervollkommnung der quantitativen Phytoplankton-Methodik. Mitt Int Ver Theor Angew Limnol. 1958; 9:1-38.

30. Carey PG. Marine interstitial ciliates: an illustrated key. London, New York: Chapman \& Hall; 1992.

31. Montagnes DJS, Strüder-Kype MC, Kype MR, Agatha S, Warwick J. The Planktonic Ciliate Project: The user-friendly guide to coastal planktonic ciliates 2001 [2014-04-01]. Available from: http://www. zooplankton.cn/ciliate/.

32. Kraberg AC, Baumann M, Dürselen C-D. Coastal Phytoplankton: Photo Guide for Northern European Seas. Munich, Germany: Pfeil; 2010. 204 p.

33. Hillebrand H, Dürselen C-D, Kirschtel D, Pollingher U, Zohary T. Biovolume calculation for pelagic and benthic microalgae. J Phycol. 1999; 35(2):403-24.

34. Putt M, Stoecker DK. An Experimentally Determined Carbon-Volume Ratio for Marine Oligotrichous Ciliates from Estuarine and Coastal Waters. Limnol Oceanogr. 1989; 34(6):1097-103.

35. Menden-Deuer S, Lessard EJ. Carbon to volume relationships for dinoflagellates, diatoms, and other protist plankton. Limnol Oceanogr. 2000; 45(3):569-79.

36. Tomas CR, Hasle GR, Syvertsen EE, Steidinger KA, Tangen K. Identifying marine phytoplankton. San Diego: Academic Press; 1997. 858 p.

37. Hoppenrath M, Elbrächter M, Drebes G. Marine phytoplankton: selected microphytoplankton species from the North Sea around Helgoland and Sylt. Stuttgart: Schweitzerbart; 2009. 264 p.

38. Shannon C, Weaver W. The mathematical theory of communication. Urbana: University of Illinois Press; 1963. $117 \mathrm{p}$.

39. Landry MR, Hassett RP. Estimating the Grazing Impact of Marine Micro-zooplankton. Mar Biol. 1982; 67(3):283-8.

40. Guillard R, Ryther J. Studies of marine planktonic diatoms. Can J Microbiol. 1962; 8:229-93. PMID: 13902807

41. Landry MR, Kirshtein J, Constantinou J. A refined dilution technique for measuring the community grazing impact of microzooplankton, with experimental tests in the central equatorial Pacific. Mar Ecol-Prog Ser. 1995; 120(1-3):53-63.

42. Calliari $D$, Tiselius $P$. Organic carbon fluxes through the mesozooplankton and their variability at different time-scales in the Gullmarsfjord, Sweden. Estuar Coast Shelf Sci. 2009; 85(1):107-17.

43. Kim JM, Lee K, Shin K, Kang JH, Lee HW, Kim M, et al. The effect of seawater $\mathrm{CO}_{2}$ concentration on growth of a natural phytoplankton assemblage in a controlled mesocosm experiment. Limnol Oceanogr. 2006; 51(4):1629-36.

44. Riebesell U, Zondervan I, Rost B, Tortell PD, Zeebe RE, Morel FMM. Reduced calcification of marine plankton in response to increased atmospheric $\mathrm{CO}_{2}$. Nature. 2000; 407(6802):364-7. doi: 10.1038/ 35030078 PMID: 11014189

45. Havenhand JN. How will Ocean Acidification Affect Baltic Sea Ecosystems? An Assessment of Plausible Impacts on Key Functional Groups. Ambio. 2012; 41(6):637-44. doi: 10.1007/s13280-012-0326-X PMID: 22926885

46. Salih F. Microalgae Tolerance to High Concentrations of Carbon Dioxide: A Review. J Envir Protect Sci. 2011; 2(5):648-54.

47. Lauritano C, Orefice I, Procaccini G, Romano G, lanora A. Key genes as stress indicators in the ubiquitous diatom Skeletonema marinoi. BMC Genomics. 2015; 16:10.

48. Feely RA, Alin SR, Newton J, Sabine CL, Warner M, Devol A, et al. The combined effects of ocean acidification, mixing, and respiration on $\mathrm{pH}$ and carbonate saturation in an urbanized estuary. Estuar Coast Shelf Sci. 2010; 88(4):442-9.

49. Melzner F, Thomsen J, Koeve W, Oschlies A, Gutowska MA, Bange HW, et al. Future ocean acidification will be amplified by hypoxia in coastal habitats. Mar Biol. 2013; 160(8):1875-88.

50. Iglesias-Rodriguez MD, Halloran PR, Rickaby REM, Hall IR, Colmenero-Hidalgo E, Gittins JR, et al. Phytoplankton calcification in a high- $\mathrm{CO}_{2}$ world. Science. 2008; 320(5874):336-40. doi: 10.1126/ science.1154122 PMID: 18420926

51. Rossoll D, Bermudez R, Hauss H, Schulz KG, Riebesell U, Sommer U, et al. Ocean acidificationinduced food quality deterioration constrains trophic transfer. PloS one. 2012; 7(4):e34737. doi: 10. 1371/journal.pone.0034737 PMID: 22509351

52. Paul AJ, Bach LT, Schulz KG, Boxhammer T, Czerny J, Achterberg EP, et al. Effect of elevated $\mathrm{CO}_{2}$ on organic matter pools and fluxes in a summer Baltic Sea plankton community. Biogeosciences. 2015; 12(20):6181-203. 
53. Riebesell U, Gattuso JP, Thingstad TF, Middelburg JJ. "Arctic ocean acidification: pelagic ecosystem and biogeochemical responses during a mesocosm study" Preface. Biogeosciences. 2013; 10 (8):5619-26.

54. Lindahl O, Belgrano A, Davidsson L, Hernroth B. Primary production, climatic oscillations, and physicochemical processes: the Gullmar Fjord time-series data set (1985-1996). ICES J Mar Sci. 1998; 55 (4):723-9.

55. Sherr EB, Sherr BF. Heterotrophic dinoflagellates: a significant component of microzooplankton biomass and major grazers of diatoms in the sea. Mar Ecol-Prog Ser. 2007; 352:187-97.

56. Stoecker DK, Capuzzo JM. Predation on Protozoa: its importance to zooplankton. J Plankton Res. 1990; 12(5):891-908.

57. Frost BW. Effects of Size and Concentration of Food Particles on Feeding Behavior of Marine Planktonic Copepod Calanus pacificus. Limnol Oceanogr. 1972; 17(6):805-15.

58. Jonsson P. Particle size selection, feeding rates and growth dynamics of marine planktonic oligotrichous ciliates (Ciliophora: Oligotrichina). Mar Ecol-Prog Ser. 1986; 33:265-77.

59. Hansen PJ, Calado AJ. Phagotrophic mechanisms and prey selection in free-living dinoflagellates. $J$ Eukaryot Microbiol. 1999; 46(4):382-9.

60. Jansen S. Copepods grazing on Coscinodiscus wailesii: a question of size? Helgoland Mar Res. 2008; 62(3):251-5.

61. De Figueiredo GM, Nash RDM, Montagnes DS. Do protozoa contribute significantly to the diet of larval fish in the Irish Sea? Journal of the Marine Biological Association of the United Kingdom. 2007; 87 (4):843-50.

62. Schnack D. Studies on feeding ecology of herring larvae. Ber Deut Wiss Komm. 1972; 22(3):273-\&

63. Bernacchi CJ, Singsaas EL, Pimentel C, Portis AR, Long SP. Improved temperature response functions for models of Rubisco-limited photosynthesis. Plant Cell Environ. 2001; 24(2):253-9.

64. Rose JM, Caron DA. Does low temperature constrain the growth rates of heterotrophic protists? Evidence and implications for algal blooms in cold waters. Limnol Oceanogr. 2007; 52(2):886-95.

65. Montagnes DJS, Lessard EJ. Population dynamics of the marine planktonic ciliate Strombidinopsis multiauris: its potential to control phytoplankton blooms. Aquat Microb Ecol. 1999; 20(2):167-81.

66. Aberle N, Bauer B, Lewandowska A, Gaedke U, Sommer U. Warming induces shifts in microzooplankton phenology and reduces time-lags between phytoplankton and protozoan production. Mar Biol. 2012; 159(11):2441-53.

67. Lischka S, Bach LT, Schulz KG, Riebesell U. Micro- and mesozooplankton community response to increasing $\mathrm{CO}_{2}$ levels in the Baltic Sea: insights from a large-scale mesocosm experiment. Biogeosciences Discuss. 2015; 12(23):20025-70. 025-2015. 